\title{
Governance of Arctic Shipping
}

Balancing Rights and Interests of Arctic States

and User States

\author{
Edited by \\ Robert C. Beckman \\ Tore Henriksen \\ Kristine Dalaker Kraabel \\ Erik J. Molenaar \\ J. Ashley Roach
}

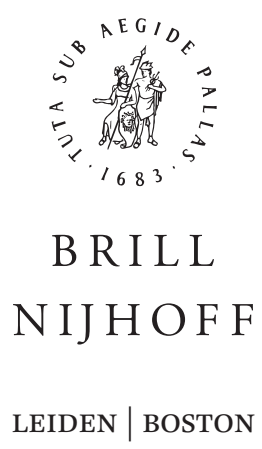

For use by the Author only | (c) 2017 Koninklijke Brill NV 


\section{Contents}

Foreword VII

Acknowledgements $\mathrm{X}$

List of Figures XI

List of Abbreviations XII

List of Contributors XVI

\section{PART 1 \\ Background and Context}

1 The Changing Maritime Arctic and New Marine Operations 3 Lawson W Brigham

2 The Arctic, the Arctic Council, and the Law of the Sea 24 ErikJ Molenaar

3 The Rights, Interests and Role of the Arctic Council Permanent Participants 68

Dalee S Dorough

\section{PART 2}

The Role of the IMO

4 The Imo, Its Role under U NCLOS and Its Polar Shipping Regulation 107 Aldo Chircop

5 The Polar Code and Its Adequacy 144

JAshley Roach

PART 3

Rights, Interests, Positions and Practice of Arctic Coastal States

6 Russia 173

Jan J Solski

For use by the Author only | (c) 2017 Koninklijke Brill NV 
$7 \quad$ Canada and the United States $\quad 217$

Donald R Rothwell

8 Norway, Denmark (in respect of Greenland) and Iceland 245 Tore Henriksen

PART 4

Rights, Interests, Positions and Practice of User States

9 Rights, Interests, Positions and Practices of Asian Flag States, with Special Reference to the Republic of Korea 299

Deukhoon (Peter) Han and Sung-Woo Lee

10 Equal Treatment and Non-discrimination for User States 318 Guifang (Julia) Xue and Yu Long

11 The Rights and Interests of Japan in regard to Arctic Shipping 357 Kentaro Nishimoto

\section{PART 5}

Cooperative Mechanisms for the Governance of Shipping

12 The Cooperative Mechanism for the Straits of Malacca and Singapore 381

Robert C Beckman and Sun Zhen

13 Oil Spill Preparedness and Response-The Singapore Experience 413

Captain M Segar

14 Conclusions on Challenges and Prospects for Enhanced Cooperation on the Governance of Arctic Shipping 432

Robert C Beckman, Tore Henriksen, Kristine Dalaker Kraabel, ErikJ

Molenaar and J Ashley Roach

Index 439 


\title{
The Arctic, the Arctic Council, and the Law of the Sea
}

\author{
ErikJMolenaar*
}

\section{1 Introduction}

The international community's interest in the Arctic increased spectacularly in the period between 2004 and 2008. Prior to that, international cooperation on the (marine) Arctic mainly involved Arctic States, and regional cooperation occurred largely by means of non-legally binding instruments and informal fora, rather than through legally binding instruments and intergovernmental organisations. The launch of the Arctic Climate Impact Assessment (ACIA $)^{1}$ in 2004 contributed to broadening recognition within the international community that climate change is largely driven by anthropogenic pollution. This recognition grew even more after the dramatic Arctic sea-ice loss in 2007,2 which spread a sense of alarm and urgency within the international community.

Another game changer was the Russian Federation's planting of its flag on the geographical North Pole's deep seabed in 2007, during the gathering of data on the outer limits of its continental shelf. The Russian Federation's flag planting triggered a number of reactions and counter-reactions. The first of these was the incorrect perception by many-e.g., media, academics, environmental non-governmental organisations (NGOs) and the European Parliament- that the flag planting heralded the last land-grab on earth and a resource bonanza that was unchecked due to an international law vacuum. This incorrect perception was then followed by the incorrect assumption that it would be logical

* Email: e.j.molenaar@uu.nl. The author is very grateful for assistance and/or comments received from Bob Beckman, Tore Henriksen, Henning Dobson Fugleberg Knudsen, Amy Merten, Alex Oude Elferink, Ashley Roach, Jan Solski and Jorden Splinter on an earlier version. All Arctic Council documents are available at http://www.arctic-council.org/index .php/en/.

1 ACIA Overview Report and the Scientific Report, accessed 15 March 2017 at http://www .amap.no/arctic-climate-impact-assessment-acia.

2 See information accessed 15 March 2017 at http://nsidc.org/. 
to fill this vacuum by a treaty modelled on the Antarctic Treaty, ${ }^{3}$ and calls to that effect. ${ }^{4}$

By means of the 2008 Ilulissat Declaration, ${ }^{5}$ the Arctic Ocean coastal StatesCanada, Denmark/Greenland, Norway, the Russian Federation, and the United States (also the 'Arctic Five') - dismissed the perception of the Arctic (Ocean) as an international law vacuum governed by a 'first-come, first-served' attitude with all the associated risks of conflicts, 'boom-and-bust' resource exploitation, and other forms of impacts on the environment and its biodiversity. The Arctic Five recalled that 'an extensive international legal framework applies to the Arctic Ocean', namely 'the law of the sea'. In fact, all global instruments apply in principle also to the entire marine Arctic and Arctic Ocean, however defined, and so does the competence of the global bodies established by these instruments. The global component of the international law of the sea is merely one domain of this global framework.

The international law of the sea is made up of a multitude of global, (sub-) regional and bilateral instruments and bodies, acts adopted by such bodies, and rules from other sources, including customary international law. The 1982 United Nations Convention on the Law of the Sea (UNCLOS) ${ }^{6}$ and its two Implementation Agreements - the Part XI Deep Seabed Mining Agreement ${ }^{7}$ and the Fish Stocks Agreement ${ }^{8}$ - function as the cornerstone of the international law of the sea. ${ }^{9}$

3 Antarctic Treaty, adopted 1 December 1959, 402 UNTS 71 (entered into force 23 June 1961).

4 See, inter alia, the EP's Resolution on 'Arctic governance' (Official Journal 2010, C 9/7; Doc P6_TA(2008)0474) para 15.

5 Ilulissat Declaration, Arctic Ocean Conference of 28 May 2008, 48 ILM 362.

6 United Nations Convention on the Law of the Sea, adopted 10 December 1982, 1833 UNTS 3 (entered into force 16 November 1994).

7 Agreement relating to the Implementation of Part XI of the United Nations Convention on the Law of the Sea of 10 December 1982, adopted 28 July 1994, 1836 UNTS 42 (entered into force 28 July 1996).

8 Agreement for the Implementation of the Provisions of the United Nations Convention on the Law of the Sea of 10 December 1982 relating to the Conservation and Management of Straddling Fish Stocks and Highly Migratory Fish Stocks, adopted 4 August 1995, 2167 UNTS 3 (entered into force 11 December 2001).

9 The envisaged Implementation Agreement on marine biodiversity in areas beyond national jurisdiction (see United Nations General Assembly Resolution 69/292, 6 July 2015, which established a Preparatory Committee (PrepCom) as a further step in the so-called 'ввNJ Process' (biodiversity in areas beyond national jurisdiction)) will eventually be part of this cornerstone as well. 
The remainder of this Chapter continues with section 2 'Maritime Zones, Boundaries and Limits in the Marine Arctic', followed by section 3 'International Disputes Relevant to the Marine Arctic', section 4 'The International Legal Framework for the Marine Arctic' and section 5 'The Arctic Council'. The Chapter finishes with section 6 'Conclusions'.

\section{2 \\ Maritime Zones, Boundaries and Limits in the Marine Arctic}

\subsection{Maritime Zones}

At present, there are no generally accepted geographical definitions for the terms 'Arctic', 'marine Arctic', 'Arctic Ocean' and 'Central Arctic Ocean'. For the purpose of this Chapter, the term 'marine Arctic' corresponds to the marine waters included within the boundary agreed by the Arctic Council's Conservation of Arctic Flora and Fauna (CAFF) working group (see Figure 2.1 below). The 'Arctic Ocean' is defined in this Chapter as the marine waters north of the Bering Strait, Greenland, Svalbard, and Franz Josef Land, thus excluding the Barents Sea.

As Iceland is located in the marine Arctic as defined in this Chapter, it qualifies as an 'Arctic coastal State'. The Arctic Five obviously also qualify as such. These six States plus Finland and Sweden are 'Arctic States' on account of their membership in the Arctic Council.

The UNCLOS recognises the following distinct maritime zones: internal waters, archipelagic waters, the territorial sea, the contiguous zone, the exclusive economic zone (EEZ), the continental shelf, the high seas and the Area (the international deep seabed). Except for archipelagic waters, all these also occur in the marine Arctic. Terms such as the 'Canadian Arctic Archipelago' and the 'Spitsbergen/Svalbard Archipelago' — even if used by Canada and Norway—do not imply that these States qualify — or claim to qualify—as archipelagic States in the domain of the international law of the sea. ${ }^{10}$

There are four high seas pockets in the marine Arctic, namely the so-called 'Banana Hole' in the Norwegian Sea, the so-called 'Loophole' in the Barents Sea, the so-called 'Donut Hole' in the central Bering Sea, and the 'high seas of the central Arctic Ocean'11 (see Figure 2.2). While it seems likely that the

$10 \quad$ UNCLOS, supra note 6 , Art 46.

11 This is the terminology used by the Arctic Five in their 'Declaration Concerning the Prevention of Unregulated High Seas Fishing in the Central Arctic Ocean', Oslo, 16 July 2015, accessed 15 March 2017 at https://www.regjeringen.no/en/aktuelt/fishing-arctic -ocean/id2427705/, as well as by the 'Five-Plus-Five' in their subsequent meetings on high 


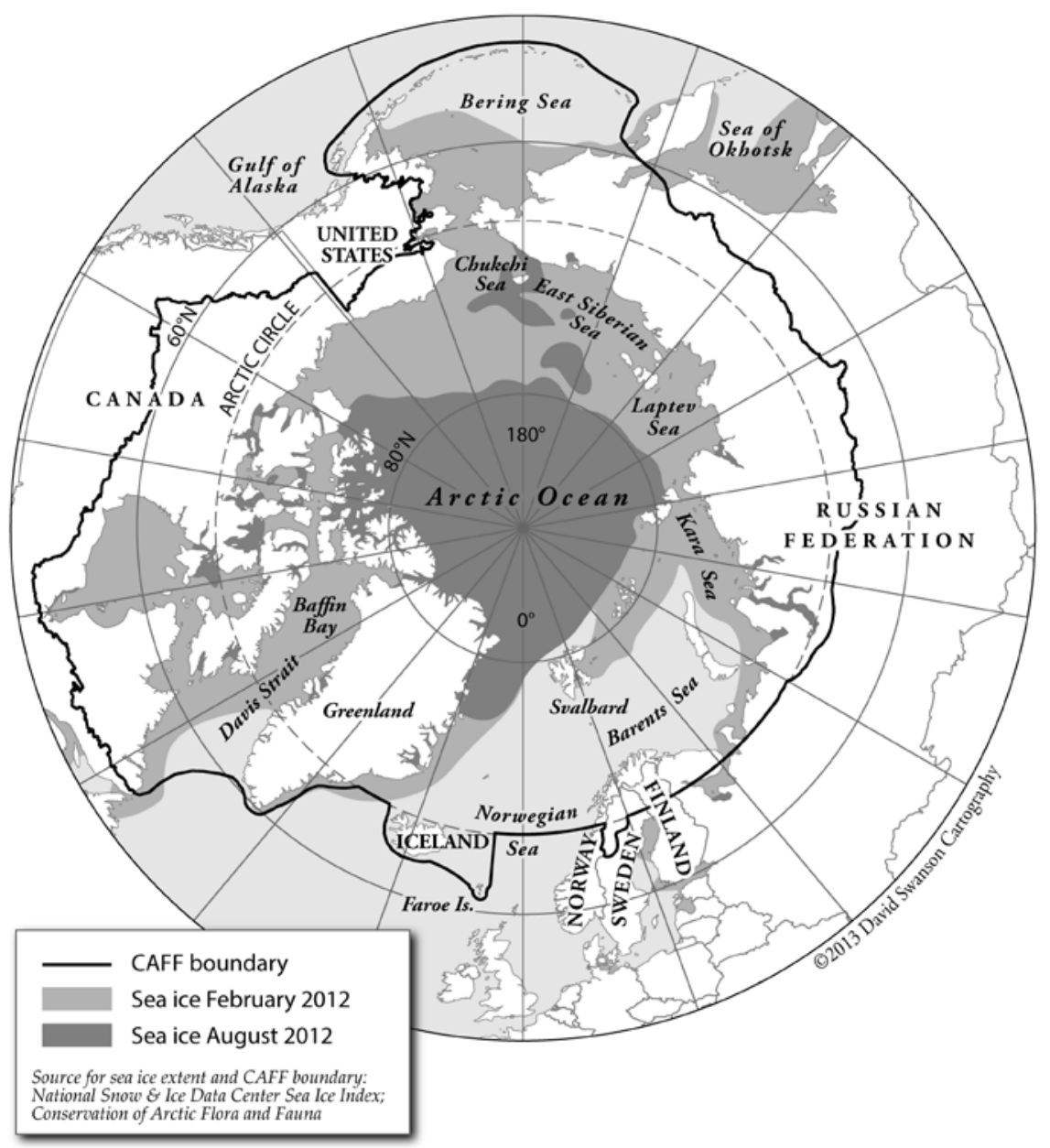

FIGURE 2.1 The Arctic region: general overview ${ }^{12}$

marine Arctic will have at least one pocket of the Area-the deep seabed beyond the continental shelves of coastal States ${ }^{13}$ — more clarity on this will take

seas fishing in the central Arctic Ocean, see e.g., http://www.dfo-mpo.gc.ca/international/ media/statement-declaration-eng.htm, accessed 15 March 2017. See also the use of 'Central Arctic Ocean' by Denmark, Iceland and Norway in the context of the OsPAR Commission's consideration of an Arctic Ice High Seas MPA' (marine protected area; see infra note 177 and accompanying text).

12 Map prepared by David Swanson and reproduced here with his permission.

13 UNCLOS, supra note 6, Art 1(1)(1). 


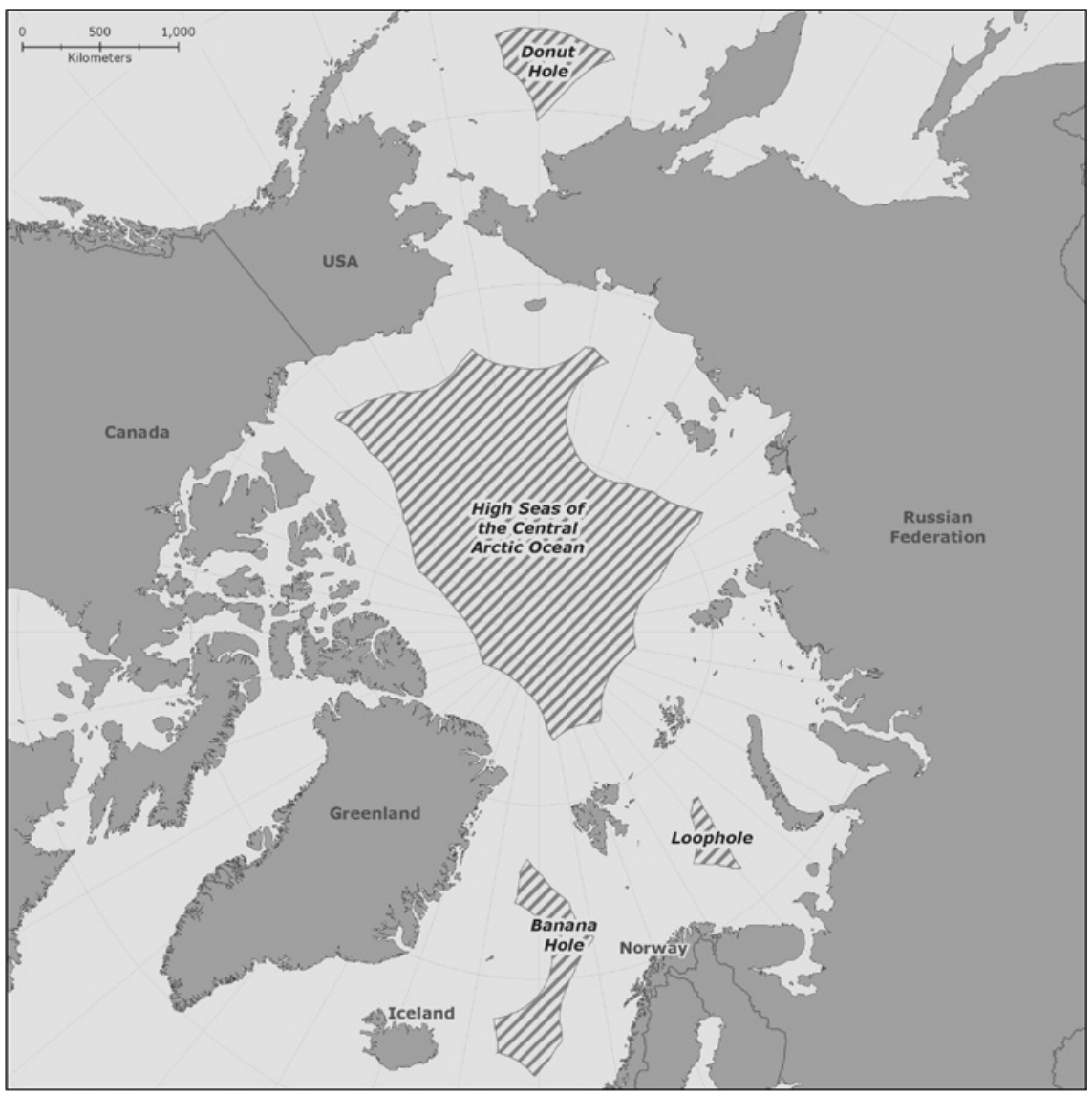

FIGURE 2.2 High seas pockets in the marine Arctic ${ }^{14}$

a considerable number of years, inter alia, due to the heavy workload of the Commission on the Limits of the Continental Shelf (CLCS) in processing submissions by coastal States.

Arctic coastal States have also established maritime zones that are not explicitly recognised by UNCLOS but are not inconsistent with it either. Examples include 'territorial waters', which comprise both (marine) internal waters and the territorial sea, ${ }^{15}$ and 200 nautical mile $(\mathrm{nm})$ maritime zones derived

14 Map used with permission of the Pew Charitable Trusts.

15 E.g., Act No 57, 27 June 2003, on Norway's Territorial Waters and Contiguous Zone. Note also that the concept of territorial waters is used in Article 2 of the 1920 Spitsbergen Treaty (Treaty concerning the Archipelago of Spitsbergen, adopted 9 February 1920, 2 LNTS (entered into force 14 August 1925)). 
from the EEZ, in which a coastal State only claims some of the sovereign rights and jurisdiction to which it is entitled pursuant to Article 56 of UNCLOS-for instance, the Fishery Zone (a de facto exclusive fishery zone (EFZ)) established by Norway around the island of Jan Mayen. ${ }^{16}$ The consistency of EFZs with international law is based on their incorporation into customary international law — probably already in the early 1970s — and the principle of in maiore stat minus (who can do more can also do less).

The Fisheries Protection Zone (FPZ) established by Norway around Svalbard in $1977^{17}$ is derived from an EFZ and relied on the EFZ's status as customary international law at the time of its establishment. Rather than designating an EFZ or even an EEZ, however, Norway opted for an FPZ to take account of the diverging views among States on the geographical scope of the Spitsbergen Treaty ${ }^{18}$ (see section 3 below).

UNCLOS also recognises the existence of so-called 'historic bays' and 'historic titles' in Articles 10(6), 15 and 298(1)(a)(i). These are part of a coastal State's internal waters-or in exceptional circumstances its territorial sea ${ }^{19}$ provided the requirements under international law on acquisition of title to territory-i.e., effective occupation demonstrated by continuous and peaceful display of State authority in conjunction with explicit recognition or acquiescence by the international community-are met. ${ }^{20}$ As examined in Chapters 6 and 7 of this Volume, both the Russian Federation and Canada have claims to historic bays or historic waters located within the marine Arctic.

Chapter 6 on the Russian Federation also examines Russia's reliance on the sector principle or theory in the Arctic, which may have had some relevance for its maritime boundaries with Norway and the United States. ${ }^{21}$ So far, however,

16 Regulations of 23 May 1980, No 4, 'establishing the fishing zone around Jan Mayen. Delegation of authority'.

17 Regulations of 3 June 1977, No 6, 'relating to a fisheries protection zone around Svalbard', as amended.

18 Supra note 15.

19 Continental Shelf (Tunisia/Libyan Arab Jamahiriya) case, Judgment of 24 February 1982, ICJ Rep 1982, at 18, para 100.

20 See also PCA Case No 2013-19 in the Matter of an Arbitration before 'An Arbitral Tribunal Constituted under Annex vir to the 1982 United Nations Convention on the Law of the Sea between the Republic of the Philippines and the People's Republic of China' (South China Sea case); Award on Jurisdiction and Admissibility, 29 October 2015, paras 398-399; Award on Merits, 12 July 2016, para 214.

21 Alex G Oude Elferink, 'Does Recent Practice of the Russian Federation Point to an Arctic Sunset for the Sector Principle?' in Suzanne Lalonde and Ted McDorman (eds), International Law and Politics of the Arctic Ocean; Essays in Honour of Donat Pharand (Brill/Nijhoff, 2015) 269-290.

For use by the Author only | (c) 2017 Koninklijke Brill NV 
Russia has not explicitly exercised coastal State jurisdiction based on the sector principle or theory and has also been in compliance with the rules and procedures on the outer limits of coastal State maritime zones laid down in UNCLOS. It will be interesting to see, however, if this remains unchanged with regard to the Russian Federation's future actions concerning its still unfinished procedure before the CLCS in relation to the geographical North Pole.

Finally, reference can be made to the practice of Norway, the Russian Federation and the United States relating to so-called 'grey areas'. These areas-which are not maritime zones proper-are located within $200 \mathrm{~nm}$ from the baselines of one State but situated on the other State's side of the maritime boundary. The EEZ-derived sovereign rights and jurisdiction in these areas have been ceded by the former State to the latter State by means of treaties. ${ }^{22}$

\subsection{Maritime Boundaries and Limits}

Various boundaries in the marine Arctic are still under negotiation, namely between Canada and Denmark/Greenland in the Lincoln Sea, and between Canada and the United States in the Beaufort Sea. Also, while boundary negotiations between the Russian Federation and the United States led to the adoption of a bilateral boundary treaty, it has only been ratified by the United States. ${ }^{23}$

As regards the continental shelf beyond $200 \mathrm{~nm}$ in the marine Arctic, the submissions by Denmark, Iceland and Norway have so far led to positive recommendations. The Russian Federation made a revised submission in respect of the Arctic Ocean in August 2015 and Denmark made a submission in respect of the Northern Continental Shelf of Greenland in December 2014. Canada made a submission in respect of the Atlantic Ocean in December 2014, while informing the CLCS that a submission in respect of the Arctic Ocean will be

22 For a discussion, see Erik J Molenaar, 'New Maritime Zones and the Law of the Sea' in H Ringbom (ed), Jurisdiction over Ships-Post-UNCLOS Developments in the Law of the Sea (Brill/Nijhoff, 2015) 249-277, at 271-274.

23 The treaty is nevertheless provisionally applied. See Robin R Churchill, 'Claims to Maritime Zones in the Arctic — Law of the Sea Normality or Polar Pecularity?' in Alex G Oude Elferink and Donald R Rothwell (eds), The Law of the Sea and Polar Maritime Delimitation and Jurisdiction (Martinus Nijhoff Publishers, 2001) 105-124; Tore Henriksen and Geir Ulfstein, 'Maritime Delimitation in the Arctic: The Barents Sea Treaty' (2011) 42 Ocean Development \& International Law 1-21; and Michael Byers, International Law and the Arctic (Cambridge University Press, 2013) at 28-91. 
made at a later date. ${ }^{24}$ It remains to be seen if the United States may-as a non-party to UNCLOS - still have the opportunity to make submissions to the CLCS. If the recommendations of the CLCS reveal an overlap between continental shelf entitlements — as is highly likely_bilateral, trilateral or perhaps even multilateral negotiations will be needed to agree on maritime boundaries relating to the outer continental shelf. ${ }^{25}$ As completion of the procedures involving the CLCS is expected to take a considerable number of years, clarity on the location of such boundaries will only materialise in the more distant future.

This overview of the maritime zones, boundaries and limits in the marine Arctic clearly illustrates that-apart from the FPZ around Svalbard-it is not significantly different from most other marine regions and Oceans. Only the Southern Ocean around the Antarctic continent stands apart, due to the disagreement on sovereignty over Antarctic land territory.

\section{International Disputes Relevant to the Marine Arctic}

The Arctic and the Antarctic are both polar regions, but are fundamentally different from the perspective of international law. The Arctic is not subject to a disagreement on sovereignty over territory that is even remotely similar to the disagreement that exists in the Antarctic. The only dispute on title to land territory in the Arctic is that between Canada and Denmark/Greenland with regard to the tiny Hans Island in the Nares Strait. ${ }^{26}$ News reports in April 2012 suggested that the dispute would soon be resolved by means of dividing the

\footnotetext{
24 For more information, see http://www.un.org/depts/los/clcs_new/commission_submis sions.htm, accessed 15 March 2017.

25 See Alex G Oude Elferink, "The Delimitation of the Continental Shelf Beyond 200 Nautical Miles in the Arctic Ocean: Recent Developments, Applicable Law and Possible Outcomes' in Myron H Nordquist, John N Moore and Ronán Long (eds) Challenges of the Changing Arctic. Continental Shelf, Navigation, and Fisheries (Brill/Nijhoff, 2016) 53-80; Byers, supra note 23 at $92-127$.

26 See Byers, supra note 23 at 10-16; the Joint Statement by the then Canadian Minister of Foreign Affairs Pettigrew and then Danish Minister of Foreign Affairs Møller made in New York on 19 September 2005, accessed 15 March 2017 at https://www.canada.ca/en/news .html); and the short article by Poul Erik Dam Kristensen, then Ambassador of Denmark to Canada, published in the Ottawa Citizen on 28 July 2005, which places the dispute in the proper perspective of the positive, on-going cooperation between the two States.
} 
island in two, ${ }^{27}$ but at the time of writing this had not (yet) happened. Shared sovereignty by means of a condominium would be an alternative option..$^{28}$ It may well be that resolution of the dispute can only be accomplished in conjunction with agreement on maritime delimitation in the Lincoln Sea and the Arctic Ocean.

Various other Arctic-specific international law of the sea disputes exist as well. First, the disagreements on the legal status of the Northwest Passage and other waters within the Canadian Arctic Archipelago, waters within the Northern Sea Route, and the consistency of associated straight baselines with international law. These disputes are examined in Chapters 6 and 7 of this Volume.

Second, the disagreement between Norway and several other parties to the Spitsbergen Treaty on the treaty's geographical scope of application (see above). Norway takes the position that the Treaty, and thereby its key provisions on equal access and non-discrimination, do not apply seaward of the outer limit of the territorial sea. A number of other parties to the Treaty, however, take the view that the Treaty applies to all maritime zones generated by Svalbard. ${ }^{29}$ In view of these different positions, Norway established an FPZ off Svalbard — while insisting on its right to establish an EEZ (or EFZ) — and allows a limited number of parties to the Treaty to fish in the FPZ, based largely on historic track records..$^{30}$ The relevance of the Spitsbergen Treaty for international merchant shipping and its regulation by Norway is examined in Chapter 8 of this Volume.

The International Legal Framework for the Marine Arctic

\subsection{Introduction}

As noted in section 1, UNCLOS and its two Implementation Agreements function as the cornerstone of the international law of the sea. They are supplemented by a multitude of global, (sub-)regional and bilateral instruments and

27 Paul Russell, 'If Hans Island falls, a piece of Canada will be lost' National Post, 11 April 2012, accessed 15 March 2017 at http://news.nationalpost.com/full-comment/todays -letters-if-hans-island-falls-a-piece-of-canada-will-be-lost.

28 See Byers, supra note 23; Bob Weber, 'Turn Hans Island into a condo to solve long-running Canada-Denmark dispute, academics suggest' National Post, 12 November 2015, accessed 15 March 2017 at http://news.nationalpost.com/news/canada/turns-hans-island-into-a -condo-academics-suggest-to-solve-long-running-canada-denmark-dispute.

29 For a discussion, see Erik J Molenaar, 'Fisheries Regulation in the Maritime Zones of Svalbard' (2012) 27 International Journal of Marine and Coastal Law 3-58.

Ibid.

For use by the Author only | (C) 2017 Koninklijke Brill NV 
bodies, acts adopted by such bodies, and rules from other sources, including customary international law. This domain is so extensive that even a concise overview cannot possibly be provided here. ${ }^{31}$

A crucial distinction in this domain is that between its global component on the one hand, and its regional, sub-regional and bilateral component on the other. Global instruments apply in principle also to the entire marine Arctic and so does the competence of the bodies established by these instruments (if any). Conversely, the geographical scope of (sub-)regional and bilateral instruments and their bodies' competence (if any) is inherently limited and is commonly explicitly specified. ${ }^{32}$ Participation in these instruments and bodies as well as their relationships and compatibility with global and other (sub-) regional and bilateral instruments and their bodies, is therefore of obvious significance.

The (sub-)regional and bilateral component of the international legal framework of the marine Arctic is highly fragmented and complex. This is partly caused by the fact that the marine Arctic comprises not only the Arctic Ocean but also parts of the North Atlantic and the North Pacific Oceans (see Figure 2.2 above). Moreover, while the Arctic Council's substantive mandate is almost unlimited, ${ }^{33}$ and the Council is at present generally accepted to be the principal intergovernmental body for Arctic cooperation, its Members do not intend the Council to eventually replace or subsume all pre-existing (sub-) regional or bilateral instruments and bodies, or to preclude new (sub-)regional or bilateral instruments and bodies from being created. Examples in this regard are instruments and bodies relating to the conservation and management of marine mammals ${ }^{34}$ and fish stocks, for instance the 1973 Agreement on the Conservation of Polar Bears ${ }^{35}$ and its Meetings of Parties (MOPs), ${ }^{36}$ and

For an overview, see The Arctic Ocean Review Phase I Report (2009-2011), available at http:// www.pame.is/, accessed 15 March 2017. See also Erik J Molenaar, Alex G Oude Elferink and Donald R Rothwell, The Law of the Sea and the Polar Regions: Interactions between Global and Regional Regimes (Martinus Nijhoff Publishers, 2013).

32 Notable exceptions are the Arctic Council (see infra note 93 and accompanying text) and the Joint Norwegian-Russian Fisheries Commission.

33 See infra note 92 and accompanying text.

34 Evan T Bloom, 'Establishment of the Arctic Council', 93 American Journal of International Law 712-722 (1999) 719-720, expects that the Arctic States will continue to avoid dealing with marine mammal issues due to the many associated sensitivities.

35 Agreement on the Conservation of Polar Bears, adopted 15 November 1973, 13 ILM 13 (entered into force 26 May 1976).

36 For information, see http://pbsg.npolar.no/en/meetings/indexı.html, accessed 15 March 2017 .

For use by the Author only | (c) 2017 Koninklijke Brill NV 
the regional fisheries management arrangement (RFMA) on high seas fishing in the central Arctic Ocean that is the likely outcome of the 'Five-Plus-Five' meetings that commenced in December 2015. ${ }^{37}$ The point of departure is that these instruments and bodies will continue to exist formally on a stand-alone basis alongside the Arctic Council.

\subsection{The Global Component Relating to International Merchant Shipping}

Regulation of international merchant shipping is predominantly carried out by global bodies, of which the International Maritime Organization (IMO) is unquestionably the most prominent. The pre-eminence of global bodies is a direct consequence of the global nature of international merchant shipping and the interest of the international community in globally uniform minimum regulation. This interest and the pre-eminence of global bodies are safeguarded in several ways by UNCLOS, whose framework on navigation can be regarded as generally accepted on account of the near-universal participation in UNCLOS ${ }^{38}$ and the fact that non-parties to UNCLOS do not have significant objections to this framework.

As explained in Chapter 4 of this Volume, UNCLOS recognises the various navigational rights and freedoms of flag States and connects flag and coastal State jurisdiction over international merchant shipping in most instances by so-called 'rules of reference' to the substantive rules and standards adopted within the IMO. So-called 'generally accepted international rules and standards' (GAIRAS) constitute a mandatory minimum for flag State jurisdiction and an optional maximum for coastal State jurisdiction. ${ }^{39}$ UNCLOS nevertheless contains a few exceptions which entitle coastal States to impose more stringent rules and standards on transiting foreign vessels. The principal exception is laid down in Article 234 entitled 'Ice-covered areas' and provides:

Coastal States have the right to adopt and enforce non-discriminatory laws and regulations for the prevention, reduction and control of marine pollution from vessels in ice-covered areas within the limits of the

37 For a discussion, see Erik J Molenaar, 'The December 2015 Washington Meeting on High Seas Fishing in the Central Arctic Ocean', post dated 5 February 2016 for The JCLOS Blog, accessed 15 March 2017 at http://site.uit.no/jclos/.

38 For information on the status of participation in UNCLOS, see http://www.un.org/depts/ los, accessed 15 March 2017.

39 The Award on the Merits in the South China Sea case, supra note 20 at para 1083, also recognises the so-called 'indirectly binding effect' of UNCLOS for parties to UNCLOS that are not also directly bound to particular GAIRAS. 
exclusive economic zone, where particularly severe climatic conditions and the presence of ice covering such areas for most of the year create obstructions or exceptional hazards to navigation, and pollution of the marine environment could cause major harm to or irreversible disturbance of the ecological balance. Such laws and regulations shall have due regard to navigation and the protection and preservation of the marine environment based on the best available scientific evidence.

Article 234 was included in UNCLOS as a result of the efforts of Canada in particular, which sought to ensure that its 1970 Arctic Waters Pollution Prevention Act (AWPPA) and underlying regulations and orders would no longer be regarded as inconsistent with international law. The negotiations on Article 234 were predominantly conducted by Canada, the then Soviet Union, and the United States, and were closely connected to what eventually became Article 211(6), which enables coastal States to impose tailor-made rules and standards in designated areas of their EEzs. ${ }^{40}$ This negotiation history does not mean, however, that any common interpretation that these three States may have with respect to Article 234, would necessarily be opposable to other parties to UNCLOS; whether flag or coastal States.

While Article 234 contains a number of ambiguities-not unlike many other provisions in UNCLOS, and in fact many other treaties - its key purpose is to provide a coastal State with broader prescriptive and enforcement jurisdiction in ice-covered areas than it would normally have in its maritime zones. In particular, in contrast with Article 211(6), Article 234 does not envisage a role for a 'competent international organization' such as the IMO in case the coastal State takes the view that more stringent standards than GAIRAS are needed.

As Article 234 indicates, jurisdiction is subject to several restrictions and can only be exercised for a specific purpose. One such restriction follows from the words 'for most of the year'. Decreasing ice-coverage will mean that Article 234 can gradually be relied on in fewer areas. At the time of writing, Canada, Denmark (in relation to Greenland), Norway (in relation to Svalbard), the Russian Federation, and the United States would be entitled to exercise jurisdiction pursuant to Article 234. Chapters 6 to 8 of this Volume examine which of these States have also actually made use of this entitlement. Whereas

40 Among the extensive body of literature on Article 234, see in particular Donald McRae, 'The Negotiation of Article 234' in Franklyn Griffiths (ed) Politics of the Northwest Passage (McGill-Queen's University Press, 1987) 98-114; and Kirstin Bartenstein, 'The "Arctic Exception" in the Law of the Sea Convention: A Contribution to Safer Navigation in the Northwest Passage?' (2011) 42 Ocean Development \& International Law 22-52. 
nothing in Article 234 or elsewhere in UNCLOS explicitly excludes its application to waters off the Antarctic continent, this is precluded at present and for the foreseeable future due to the fundamental disagreement on title to territory in Antarctica and the consequential absence of universally recognised coastal States in Antarctica.

As regards the phrase 'within the limits of the exclusive economic zone', it is submitted that the better interpretation is that this merely indicates the outer limits of the EEZ, and does not exclude the territorial sea. ${ }^{41}$ This interpretation is consistent with a key feature of the international law of the sea, namely more comprehensive State authority in coastal State maritime zones closer to the coast compared to more distant coastal State maritime zones. Moreover, foreign vessels will in most — if not all — scenarios have to pass through an EEZ before or after navigating through a territorial sea. A requirement to comply with unilateral so-called 'static' (i.e., continuously applicable) standardsi.e., construction, design, equipment and manning (CDEM) standards-while navigating in an EEZ, implies that these will also be complied with during navigation in the adjacent territorial sea. Finally, within their territorial seas, Article 21(2) of UNCLOS provides coastal States at any rate with a separate exception to impose unilateral standards other than CDEM standards (e.g., discharge and navigation standards).

The purpose for which jurisdiction can be exercised pursuant to Article 234 is 'the prevention, reduction and control of marine pollution from vessels'. Even though 'navigation' is mentioned twice in Article 234, it does not explicitly grant jurisdiction for the purpose of ensuring maritime safety. It is nevertheless submitted that Article 234 allows regulations that have environmental protection as a primary purpose and maritime safety as a secondary purpose as well as regulations for which both purposes are more or less equally important. ${ }^{42}$

UNCLOS does not explicitly address the scenario of waters that are both icecovered and subject to the regime of transit passage, but many commentators argue that the inclusion of the stand-alone Article 234 in the separate Section

\footnotetext{
41 Bartenstein, supra note 40 at 29, eventually favours a literal interpretation, thus excluding the territorial sea.

42 See also paragraph 5 of the Preamble to the International Code for Ships Operating in Polar Waters (Polar Code; IMO Doc ME PC 68/21/Add.1, 5 June 2015, Annex 10), which stipulates: 'The relationship between the additional safety measures and the protection of the environment is acknowledged as any safety measure taken to reduce the probability of an accident, will largely benefit the environment'.
} 
8 of Part XII supports the dominance of Article 234 over transit passage. ${ }^{43}$ The International Chamber of Shipping (ICS) supported the opposite view in 2014. ${ }^{44}$ Chapters 6 to 11 of this Volume will examine the positions that Arctic coastal States and user States may have in this regard.

\subsection{Regional Cooperation and the Law of the Sea}

UNCLOS and the Fish Stocks Agreement are in many ways framework conventions and do not contain the substantive (material) standards that are necessary for actual regulation, for instance safety standards to deal with cases like the sinking of the Titanic or conservation and management measures to prevent overfishing of target species or by-catch of non-target species. Regulation by States individually cannot provide effective solutions for human activities with an inherent or potential transboundary dimension, and multilateral cooperation at the appropriate level is therefore essential.

Which level of regulation - bilateral, (sub-)regional or global-is appropriate, depends mainly on the activity itself. If activities or their impacts are not confined to a particular region-for instance international merchant shipping and activities that produce greenhouse gases-they are often best regulated at the global level. Regional regulation can, for example, be necessary due to the spatial distribution of particular species or habitats, or the spatial reach of land-based and/or marine pollution. Enclosed or semi-enclosed seas, like the Black and Mediterranean Seas, are obvious candidates for regional approaches, as is also reflected in Article 123 of UnCLOs. Regional regulation may also be able to create a level playing field and regional uniformity, which could, inter alia, be attractive to companies that operate in multiple jurisdictions or consider doing so.

Regional regulation has disadvantages as well. Often, regulation can only be applied on an inter se basis-as between the regional States-due to the pacta tertiis principle. States that have not consented to such regulation therefore enjoy 'free rider' benefits. The pacta tertiis problem can manifest itself in various ways, for instance by vessels of third States that operate in the region itself or by transboundary impacts from outside the region. More stringent

43 E.g., Kari Hakapää, Marine Pollution in International Law. Material Obligations and Jurisdiction, (Suomalainen Tiedeakatemia, 1981) 258; McRae, supra note 40 at 110; and Donat Pharand, 'The Arctic Waters and the Northwest Passage: A Final Revisit' (2007) 78 Ocean Development \& International Law 3-69, at 29.

44 Arctic Shipping. Position Paper, ICS, 2014, at para 4, accessed 15 March 2017 at www.ics -shipping.org. 
regional regulation can also create competitive disadvantages in comparison with other regions.

UNCLOS encourages or imposes (qualified) obligations to cooperate at the regional level. ${ }^{45} \mathrm{~A}$ similar approach is pursued by various global organisations and their instruments that are part of the global framework of the law of the sea. As a consequence, regional cooperation exists, inter alia, in the following fields: ${ }^{46}$

1. Merchant shipping: see next subsection;

2. Pollution incidents: including but not limited to incidents relating to merchant shipping-whether by means of monitoring, control and surveillance, ${ }^{47}$ or contingency planning, preparedness and response (e.g., the Arctic MOSPA ${ }^{48}$ and its MOPs);

3. Search and rescue: including but not limited to incidents relating to merchant shipping - for instance through the Arctic SAR Agreement ${ }^{49}$ and its MOPs;

4. Marine environmental protection: in particular through Regional Seas programmes - the majority of which are supported or coordinated by the United Nations Environment Programme (UNEP) ${ }^{50}$ —and large marine

45 E.g., Part V (Arts 63-67) and Part XII (Arts 198-200).

46 For a more comprehensive overview, see Erik J Molenaar, 'Current and Prospective Roles of the Arctic Council System within the Context of the Law of the Sea' (2012) 27 International Journal of Marine and Coastal Law 553 at $55^{8-565 .}$

47 For instance, by means of the Bonn Agreement (Agreement for Cooperation in Dealing with Pollution of the North Sea by Oil and Other Harmful Substances, adopted 13 September 1983, OJ 1984, L 188/9, as amended (entered into force 1 September 1989)), or in the framework of the Helsinki Commission (НЕLCOM; operating pursuant to the 1992 Helsinki Convention (Convention on the Protection of the Marine Environment of the Baltic Sea Area, signed 9 April 1992, 2099 UnTs 197, as amended (entered into force 17 January 2000)). See in particular the HЕLсом Response Working Group and its Informal Working Group on Aerial Surveillance, see information at http://www.helcom .fi/helcom-at-work/groups/response/iwgas, accessed 15 March 2017.

48 Agreement on Cooperation on Marine Oil Pollution Preparedness and Response in the Arctic, adopted 15 May 2013 (entered into force 25 March 2016), accessed 15 March 2017 at http://www.arctic-council.org/index.php/en/our-work/agreements.

49 Agreement on Cooperation in Aeronautical and Maritime Search and Rescue in the Arctic, adopted 12 May 2011, 50 ILM 1119 (entered into force 19 January 2013).

50 See http://www.unep.org/regionalseas/, accessed 15 March 2017. 
ecosystem (LME) mechanisms, many of which are supported by the Global Environment Facility (GEF) ${ }^{51 ; 52}$

5. Conservation and management of marine living resources: including through regional fisheries management organisations (RFMOS) and RFMAs, other types of regional fisheries bodies (RFBs; including those (also) dealing with marine mammals $)^{53}$ as well as regional bodies exclusively aimed at the conservation of marine species; and

6. Marine scientific research, for example through the International Council for the Exploration of the Sea (ICES), the North Pacific Marine Sciences Organization (PICES), and the Arctic Scientific Cooperation Agreement ${ }^{54}$ that was negotiated under the auspices of the Arctic Council at the time of writing.

Owing to the large number and considerable diversity of these regional bodies and their instruments, it is not possible to provide even a concise overview of their key features and differences; not even those relating to the marine Arctic. ${ }^{55}$ One aspect is nevertheless worth singling out: as a general rule, the States participating as full members in these regional regimes do so in their capacity as a coastal State. There are two exceptions to this general rule: the instruments of the Antarctic Treaty System, and RFMOs or RFMAs whose regulatory areas consist partially or entirely of high seas. The former exception is directly linked to the agreement to disagree on the question of sovereignty over land territory in Antarctica, and the latter is a result of the freedom of high seas fishing. The Arctic Council is not covered by these two exceptions. As discussed in section 5 , only regional States can be Members of the Council and this is in principle consistent with international law.

51 See, inter alia, http://www.lme.noaa.gov/ and http://iwlearn.net/, both accessed 15 March 2017.

$5^{2} \quad$ For an overview, see Julien Rochette, Raphaël Billé, Petra Drankier, Erik Molenaar and Lucien Chabason, 'Regional Oceans Governance Mechanisms: A Review' (2015) 6o Marine Policy 9-19.

53 See the RFBs-list, accessed 15 March 2017 at http://www.fao.org/fishery/rsn/en; Rochette et al., supra note $5^{2}$.

54 Agreement on Enhancing International Arctic Scientific Cooperation, Fairbanks, 11 May 2017. Not in force; accessed at 19 June 2017 at http://www.arctic-council.org/index.php/ en/our-work/agreements.

55 For some literature, see supra note 31. 


\subsection{Regional Cooperation Relating to Merchant Shipping \\ 4.4.1 Regulation}

As concluded above, UNCLOS does not require or encourage regional regulation in the domain of merchant shipping, as this would undermine UNCLOs's objective of globally uniform minimum standards and the related primacy of the IMO. This notwithstanding, UNCLOS explicitly allows unilateral prescription by coastal States in some scenarios-one of which is Article 234-and implicitly by port and flag States more generally. Nothing in UNCLOS prevents coastal, port or flag States from exercising these rights collectively at the regional level. The legality of regional residual port State prescriptive jurisdiction is in fact acknowledged by Article 211(3) of UNCLOS, which merely requires regional States to give due publicity to such action.

Moreover, IMO practices and several of its instruments explicitly acknowledge a State's residual prescriptive jurisdiction in its capacity as a port State, ${ }^{56}$ as a coastal State (e.g., in relation to ballast water exchange and anchoring) or in all three capacities (i.e., as a flag, port or coastal State), provided such exercise is consistent with international law. ${ }^{57}$ It is nevertheless understandable that the official position by IMO Members on regional regulation is that this should be avoided in view of the risk it poses to the IM o's authority and the desirability of globally uniform minimum standards. ${ }^{58}$ As such a risk is in principle not posed

56 E.g., Regulation 21(8)(2) of Annex I to MARPOL $73 / 78$ (International Convention for the Prevention of Pollution from Ships, adopted 2 November 1973 (as modified by the 1978 Protocol adopted on 1 June 1978 and the 1997 Protocol adopted on 26 September 1997), 1340 UNTS 61, and as regularly amended. Entry into force varies for each Annex. At the time of writing Annexes I-VI were all in force).

57 E.g., Article 1(3) of the AFS Convention (International Convention on the Control of Harmful Anti-fouling Systems on Ships, adopted 5 October 2001 (entered into force 17 September 2008), Imo Doc AFS/CONF/26, 18 October 2001); Article 2(3) of the BWM Convention (International Convention for the Control and Management of Ships' Ballast Water and Sediments, adopted 13 February 2004 (scheduled to enter into force on 8 September 2017), Iмо Doc вWм/CONF/36, 16 February 2004; Reg XI-2/2(4) of solas 74 (International Convention for the Safety of Life at Sea, adopted 1 November 1974, 1184 UNTS 277 (entered into force 25 May 1980), with protocols and regularly amended) and para B/4.34 of the International Ship and Port Facility Security Code (ISPS Code; IMo Doc SOLAS/CONF.5/34, of 17 December 2002).

$5^{8}$ See e.g., Iмо Assembly Resolution A.1097(29), 1 December 2015, 'Strategic Plan for the Organization (for the six-year period 2016-2021)' at para 2.3, which reads—in part—-that the challenge for IMO is to 'provide an effective and efficient response to shipping trends, developments and incidents, and in so doing, stave off regional or unilateral tendencies which conflict with the Organization's regulatory framework'. See also Olav S Stokke, 'Regime interplay in Arctic shipping governance: explaining regional niche selection' (2013) 13 International Environmental Agreements: Politics, Law and Economics 65-85.

For use by the Author only | (C) 2017 Koninklijke Brill NV 
by (anticipatory) regional implementation of IMO instruments in a manner that respects the pacta tertiis principle, however, this is explicitly allowed or even encouraged. This has for instance led the Arctic Council to pursue regional implementation of the IMO's SAR Convention ${ }^{59}$ by means of the Arctic SAR Agreement ${ }^{60}$ and regional implementation of the IMO's OPRC $90^{61}$ and Intervention Convention ${ }^{62}$ by means of the Arctic MOSPA. ${ }^{63}$ Another example is the anticipatory - but recommendatory - regional implementation of aspects of the BWM Convention ${ }^{64}$ pursued jointly by the Members of the OSPAR Commission, ${ }^{65}$ HELCOM $^{66}$ and the parties to the Barcelona Convention ${ }^{67.68}$

These instances of (anticipatory) regional implementation do not affect other States: the first two instances because they only implement and operationalise coastal State obligations and the last because it is pursued exclusively on a flag State basis (even though within a specified geographical area). ${ }^{69}$

59 International Convention on Maritime Search and Rescue, adopted 27 April 1979, 1405 UNTS 118 (entered into force 22 June 1985) as amended.

6o See supra note 49 .

61 International Convention on Oil Pollution Preparedness, Response and Cooperation, adopted 30 November 1990, 1891 UnTs 77 (entered into force 13 May 1995).

62 International Convention relating to Intervention on the High Seas in Cases of Oil Pollution Casualties, adopted 29 November 1969, 970 UNTS 211 (entered into force 6 May 1975).

63 See supra note 48.

64 See supra note 57.

65 Established by the ospar Convention (Convention for the Protection of the Marine Environment of the North-East Atlantic, adopted 22 September 1992 (entered into force 25 March 1998), 2345 UNTS 67, as amended. Annex V 'On the Protection and Conservation of the Ecosystems and Biological Diversity of the Maritime Area', adopted 23 September 1998 (entered in force 30 August 2000) as amended, consolidated text available at www .ospar.org.

66 See supra note 47.

67 Convention for the Protection of the Marine Environment and the Coastal Region of the Mediterranean, adopted 10 June 1995 (entered into force 9 July 2004) accessed 15 March 2017 at http://web.unep.org/unepmap/.

68 Joint Notice to Shipping from the Contracting Parties of the Barcelona Convention, OSPAR and HELCOM on: 'General Guidance on the Voluntary Interim Application of the Di Ballast Water Exchange Standard by Vessels Operating between the Mediterranean Sea and the North-East Atlantic and/or the Baltic Sea' (Annex 17 to 2012 OSPAR Summary Record).

69 See the acknowledgment of the Imo's primacy in Article 4(2) of Annex V to the ospar Convention, supra note 65 , as well as the more general requirement for consistency with international law included in Article 6 of the Barcelona Convention, supra note 67. 
Another example of a flag State approach is Annex IV on 'Prevention of Marine Pollution' of the Protocol on Environmental Protection to the Antarctic Treaty. ${ }^{70}$

There are in fact very few examples of regional exercises of residual coastal or port State prescriptive jurisdiction that affect third States. The main exception is the European Union (EU), which has exercised residual jurisdiction in a (de facto) port, coastal and flag State capacity. ${ }^{71}$ In addition, various regulations in Annex IV to the Helsinki Convention ${ }^{72}$ constitute residual prescriptive jurisdiction in all three capacities as well. ${ }^{73}$

\subsubsection{Enforcement}

As regional cooperation and coordination on enforcement does not undermine globally uniform minimum standards, it is not prohibited or constrained by UNCLOS. Whereas UNCLOS does not encourage such regional action either, the 1991 Imo Assembly Resolution A.682(17) 'Regional Co-operation in the Control of Ships and Discharges' did, and triggered the creation of a global network of regional arrangements on port State control (PSC) modelled on the then already almost decade-old Paris Mou. ${ }^{74}$ These regional PSC Arrangements for merchant shipping were established to enhance compliance with internationally agreed standards by means of commitments to carry out harmonised and coordinated inspections and to take predominantly corrective enforcement action (i.e., detention for the purpose of rectification). The instruments in which these internationally agreed standards are contained are commonly referred to as the 'relevant instruments', and include the main Imo instruments. A participating Maritime Authority will only apply relevant instruments that are not just in force generally but also for that Maritime Authority. ${ }^{75}$ Some applicability gaps can therefore be expected.

70 Annexes I-IV, adopted 4 October 1991 (entered into force 14 January 1998) accessed 15 March 2017 at http://www.ats.aq.

71 See, inter alia, Henrik Ringbom, The eu Maritime Safety Policy and International Law (Martinus Nijhoff Publishers, 2008); and Veronica Frank, The European Community and Marine Environmental Protection in the International Law of the Sea. Implementing Global Obligations at the Regional Level (Martinus Nijhoff Publishers, 2007) 227-257.

72 See supra note 47.

73 In particular Regulations 4-6, some of which are based on EU enactments.

74 Memorandum of Understanding on Port State Control, adopted 26 January 1982 (in effect 1 July 1982), as regularly amended, consolidated version accessed 15 March 2017 at https:// www.parismou.org/. This Chapter uses the version including the 39th amendment, in effect 1 July 2016. 
The Arrangements are non-legally binding and-rather than States as such-Maritime Authorities are parties to them. ${ }^{76}$ Saving-clauses have nevertheless been incorporated in the Arrangements to ensure that nothing in them affects residual port State jurisdiction, which includes the right to take more onerous enforcement measures. ${ }^{77}$

The expansion in participation in the Paris Mou and the creation and expansion of eight new arrangements since then ${ }^{78}$ means that almost complete global coverage has now been achieved. ${ }^{79}$ While the Arctic Ocean/region and the Southern Ocean/Antarctic region constitute gaps in global coverage, this does not necessarily mean that these gaps require the establishment of new regional PSC Arrangements. ${ }^{80}$

Whereas regional PSC Arrangements are primarily aimed at addressing non-compliance by ships, account can also be taken of the performance of the flag States of these ships. The Paris Mou, for instance, not only requires its Maritime Authorities to detain a ship to ensure that deficiencies are rectified, but also to refuse a ship access to port following multiple detentions. ${ }^{81}$ Refusal of access to port depends among other things on whether or not the flag State appears on the annual grey or black lists. ${ }^{82}$

Finally, mention should be made of the following regional mechanisms aimed at enforcement of vessel-source pollution violations:

1. The North Sea Network of Investigators and Prosecutors (NSN), which is a body established in 2002 by the OSPAR Commission in order to facilitate

76 Erik J Molenaar, 'Port State Jurisdiction: Toward Comprehensive, Mandatory and Global Coverage' (2007) 38 Ocean Development \& International Law 225 at 227.

77 E.g., Paris MOU, supra note 74, Secs 1.7 and 9.1.

78 I.e., Asia and the Pacific (Tokyo Mou); Latin America (Acuerdo de Viña del Mar); Caribbean (Caribbean MOU); West and Central Africa (Abuja MOU); the Black Sea region (Black Sea MOU); the Mediterranean (Mediterranean MOU); the Indian Ocean (Indian Ocean MOU); and the Arab States of the Gulf (Riyadh Mou).

79 See the information at http://www.imo.org/en/OurWork/MSAs/Pages/PortStateControl .aspx, accessed 15 March 2017.

8o As regards the Arctic region, see Erik J Molenaar, 'Options for Regional Regulation of Merchant Shipping Outside IMo, with Particular Reference to the Arctic Region' (2014) 45 Ocean Development \& International Law 272 at 284-287. The Paris Mou's Port State Control Committee adopted PSC inspection guidelines on the Polar Code at its 2016 Annual Meeting and forwarded them to the Secretariat of the Tokyo Mou for information.

81 See Paris mou, supra note 74, Secs 3.4-3.13.

82 Ibid., Sec 4. See the 2015 Paris Mou Annual Report, accessed 15 March 2017 at https://www .parismou.org/). 
enforcement of international regulation of vessel-source pollution in the North Sea, in close cooperation with the Bonn Agreement; ${ }^{83}$

2. The efforts of HELCOM towards harmonised and effective cooperation on enforcement of vessel-source pollution violations; ${ }^{84}$ and

3. The efforts of the $\mathrm{EU}$, including on penalties for vessel-source pollution offences ${ }^{85}$ and the establishment of the European Maritime Safety Agency (EMSA), tasked among other things with operating various information systems, thereby reinforcing and supporting the enforcement capability of $\mathrm{EU}$ Member States in their capacities as port and coastal States. ${ }^{86}$

\subsubsection{Other Domains of Cooperation}

Regional cooperation relating to merchant shipping may also relate to other domains than regulation and enforcement. Some examples are:

1. The extensive cooperation between strait States and user States with respect to the Straits of Malacca and Singapore examined in Chapter 12;

2. Cooperation relating to hydrography, which safeguards safe shipping as well as the scientific basis for regulation by other bodies. As regards the Arctic, reference can be made to the Arctic Regional Hydrographic Commission (ARHC) established in October $2010 ;^{87}$ and

3. Cooperation between coast guards, which commonly extends beyond issues of merchant shipping. As regards the Arctic, mention can be made

83 See information at http://www.ospar.org/about/international-cooperation/north-sea -network, accessed 31 December 2016.

84 E.g., HelCom Recommendations 19/14, 26 March 1998, and 19/16, 24 March 1998, accessed 15 March 2017 at http://www.helcom.fi/.

85 Directive 2005/35/EC, 7 September 2005, 'on ship-source pollution and on the introduction of penalties, including criminal penalties, for pollution offenses', OJ 2005, L 255/11, as amended.

86 See information at http://www.emsa.europa.eu/, accessed 15 March 2017; and Markku Mylly, 'EMSA's Role in Making the Maritime Regulatory System Work: Supporting Compliance through Monitoring and Enforcement' in Marta Chantal Ribiero and Erik J Molenaar (eds), Maritime Safety and Environmental Protection in Europe. Multiple Layers in Regulation and Compliance (Gráfica Ediliber, 2015) 175-203, accessed 15 March 2017 at http://www.marsafenet.org/scientific-publications/.

87 For information, see www.iho.int/srvi/index.php?option=com_content\&view=article\&id =435\&Itemid=69o\&lang=en, accessed 15 March 2017 . 
of the establishment of the Arctic Coast Guard Forum (ACGF) by 'Agencies Representing Coast Guard Functions' of all Arctic States in October 2015. ${ }^{88}$

\section{$5 \quad$ The Arctic Council}

\subsection{Introduction}

The Arctic Council was established in 1996 as a high-level intergovernmental forum by the Ottawa Declaration. ${ }^{89}$ The choice for a non-legally binding instrument is a clear indication that the Council was not intended to be an intergovernmental organisation. Canada in particular advocated in the mid1990 s that the Council should be an intergovernmental organisation, ${ }^{90}$ but the United States especially could not be convinced.

The Council's mandate broadened pre-existing cooperation under the 1991 Arctic Environmental Protection Strategy (AEPS) ${ }^{91}$ to:

promoting cooperation, coordination and interaction among the Arctic States, with the involvement of the Arctic indigenous peoples and other Arctic inhabitants on common Arctic issues, in particular issues of sustainable development and environmental protection in the Arctic. ${ }^{92}$

88 The ACGF was established pursuant to the 'Joint Statement of the Intent to Further Develop Multilateral Cooperation of Agencies Representing Coast Guard Functions', adopted on 30 October 2015 (on file with author). At the very end, the ACGF Joint Statement approves the ACGF Terms of Reference (ACGF Terms of Reference (on file with author)) 'as the foundation upon which to build the multilateral cooperation mechanism in the Arctic region'. See also Andreas Østhagen, 'The Arctic Coast Guard Forum: Big Tasks, Small Solutions', accessed 15 March 2017 at http://www.thearcticinstitute.org/ the-arctic-coast-guard-forum-big-tasks/.

89 'Declaration on the Establishment of the Arctic Council, Ottawa, 19 September 1996'. For a general discussion on the Arctic Council, see Piotr Graczyk and Timo Koivurova, 'The Arctic Council' in Leif C Jensen and Geir Hønneland (eds), Handbook of the Politics of the Arctic (Edward Elgar Publishing, 2015) 298-327.

90 Donald R Rothwell, The Polar Regions and the Development of International Law (Cambridge University Press, 1996) at 243; and Yoshinobu Takei, 'The Role of the Arctic Council from an International Law Perspective: Past, Present and Future' (2015) VI Yearbook of Polar Law 349-374.

91 Adopted 14 June 1991, 30 ILM 1624 (1991).

92 Ottawa Declaration, supra note 89, Art $1(\mathrm{a})$. 
While the substantive mandate of the Council thus relates in particular to sustainable development and environmental protection, it is otherwise only subject to the restriction of 'common Arctic issues'. A footnote to Article 1 specifies, however, that the Council 'should not deal with matters related to military security'. The use of the voluntary term 'should'-which is appropriate for a non-legally binding instrument-nevertheless indicates that the Council could deal with such matters anyway, provided there is consensus to do so. In fact, as the Ottawa Declaration is not legally binding, it does not pose much of an obstacle to the Members if they would wish to go even beyond the already very broad mandate of the Council.

The Ottawa Declaration does not specify the geographical mandate of the Arctic Council and, as indicated earlier, there is no generally accepted geographical definition of the term 'Arctic'. Accordingly, different components and outputs of the Arctic Council can have different geographical scopes. ${ }^{93}$ This is by no means unique; a similar approach has been pursued in the Antarctic Treaty System, where the spatial scope of the CAMLR Convention ${ }^{94}$ includes a more northerly marine area that is not included in the spatial scope of the Antarctic Treaty. ${ }^{95}$

The Arctic Council has three categories of participation: Members, Permanent Participants and Observers. All eight Arctic States are Members; in fact - as noted above - they are Arctic States on account of their establishment of the Council and its predecessor, the AEPS. ${ }^{96}$ As neither the Ottawa Declaration nor the Council's Rules of Procedure ${ }^{97}$ entitle non-Arctic States or entities to become Members, the Council is essentially 'closed'. This is in principle consistent with international law. In view of the Council's current mandate and main approaches, current international law does not provide non-Arctic States and entities with a clearly applicable and unqualified entitlement to become a Member. The situation would, for example, be different if the Council were to engage in regulation that interferes with rights of third States or entities (e.g., the freedoms of fishing and navigation on the high seas)

93 E.g., Arctic SAR Agreement, supra note 49, Art 3(1) and Annex, para (1); Arctic mosPA, supra note 48, Art 3(1) and (2); and Arctic Scientific Cooperation Agreement, supra note 54, Art 1 and Annex 1.

94 Convention on the Conservation of Antarctic Marine Living Resources, adopted 20 May 1980, 1329 UNTS 47 (entered into force 7 April 1982) Art 1.

95 Art IV.

96 See also Art 1 of the Arctic Council Rules of Procedure (most recent version adopted by the Kiruna Ministerial Meeting (2013)). 
in a manner that would be inconsistent with the pacta tertiis principle (e.g., by means of at-sea high seas enforcement). ${ }^{98}$

There are currently six Permanent Participants, namely the Arctic Athabaskan Council (AAC), the Aleut International Association (AIA), the Gwich'in Council International (GCI), the Inuit Circumpolar Council (ICC), the Russian Arctic Indigenous Peoples of the North (RAIPON) and the Saami Council. Article 2 of the Ottawa Declaration opens the door to new Permanent Participants, provided that one of the two criteria included in Article 2 is met and that the number of Permanent Participants remains smaller than the number of Members. This means that there is at present room for one more Permanent Participant. Chapter 3 of this Volume provides an in-depth examination of the interests and roles of the Permanent Participants in relation to Arctic shipping.

Subsection 5.2 devotes more in-depth attention to the third participatory category in the Arctic Council: Observers.

Decision-making within the Council occurs by consensus among the Members. ${ }^{99}$ While the Permanent Participants are not entitled to participate in formal decision-making, they have considerable influence in the decisionformation phase prior to formal decision-making, due to the purposes for which the category of Permanent Participants was created, namely 'active participation and full consultation with the Arctic indigenous representatives within the Arctic Council'. ${ }^{100}$ Finally, as the Council is 'merely' a highlevel intergovernmental forum, it cannot adopt legally binding decisions or instruments. The legally binding Arctic SAR Agreement and the Arctic MOSPA were negotiated within Task Forces established by the Council, and thereby under its auspices. However, their formal adoption and signature took place by ad-hoc diplomatic conferences held in conjunction with the Nuuk (2011) and Kiruna (2013) Ministerial Meetings. This has given rise to the concept of the ACs discussed in subsection 5.4. The 2017 Ministerial Meeting is intended to be used for the signature of the Arctic Scientific Cooperation Agreement that was negotiated within the Scientific Cooperation Task Force (SCTF) at the time of writing.

The operation of the Arctic Council revolves around the bi-annual Ministerial Meetings where, inter alia, the Council's output is formally approved or endorsed, new projects and future work plans are adopted, and

98 See Molenaar, supra note 46 at $565^{-568 .}$

99 Article 7 of the Ottawa Declaration and Rules 7 and 8 of the Arctic Council Rules of Procedure.

100 Rule 5 of the Arctic Council Rules of Procedure. 
other important decisions, for instance on applications for Observer status, are made. The Council is formally led by a bi-annual rotating chairmanshipheld by the United States between 2015 and 2017 - and assisted by the Arctic Council Secretariat—based in Tromsø, Norway-led by its Director. The Chair is not only responsible for preparing for the next Ministerial Meeting - in particular to ensure that targets agreed at the previous Ministerial Meeting are met-but also for the Senior Arctic Officials (sAOs) meetings generally held twice each year, as well as the day-to-day operation of the Council. ${ }^{101}$

Most of the substantive work of the Council takes place within its six 'permanent' Working Groups, namely:

1. Arctic Contaminants Action Program (ACAP);

2. Arctic Monitoring and Assessment Programme (AMAP);

3. Conservation of Arctic Flora and Fauna (CAFF);

4. Emergency Prevention, Preparedness and Response (EPPR);

5. Protection of the Arctic Marine Environment (PAME); and

6. Sustainable Development Working Group (sDWG).

Besides establishing additional 'permanent' working groups, the Council can also establish bodies with a limited period of operation, namely Task Forces or other subsidiary bodies (e.g., Expert Groups). ${ }^{102}$ As noted above, three legally binding instruments have been negotiated within such Task Forces.

\subsection{Arctic Council Observers}

The status of Observer with the Arctic Council is available for three categories of entities, namely (a) non-Arctic States; (b) inter-governmental and interparliamentary organisations, global and regional; and (c) NG Os. ${ }^{103}$ As at 19June 2017, there were a total of 39 Observers; with 13 in category (a), 13 in category (b) and 13 in category (c). ${ }^{104}$ Table 2.1 below provides an overview of the non-Arctic States that held, or had applied for, Observer status at the time of writing. In the context of this Volume, it is worth highlighting that the four most important Asian shipping States-China, Japan, Korea (вок) and Singapore-all had Observer status at the time of writing.

101 The Arctic Council Rules of Procedure, which were last revised in 2013, envisage no role for Deputy Ministers' Meetings. Two such Meetings have been held so far, in May 2010 and in May 2012. See Graczyk and Koivurova, supra note 89 at 308.

102 Rule 28 of the Arctic Council Rules of Procedure.

103 Article 3 of the Ottawa Declaration and Rule 36 of the Arctic Council Rules of Procedure.

104 The information was accessed 19 June 2017 at http://arctic-council.org/index.php/en/ about-us/arctic-council/observers.

For use by the Author only | (C) 2017 Koninklijke Brill NV 
The 2015 Iqaluit Ministerial Meeting deferred a decision on all then pending applications for Observer status 'with the goal of deciding on them' at the upcoming 2017 Fairbanks Ministerial Meeting. ${ }^{105}$ This seemed to a considerable extent due to diverging positions on how to deal with the EU application. The EU applied for category (b) Observer status prior to the 2009 Tromsø Ministerial Meeting, but a final decision on its application is still forthcoming. The lack of consensus for approving the EU's application was initially caused by its (consideration of) restrictions on the import of seal products and subsequently (also) by its sanctions on the Russian Federation following Russia's annexation of Crimea in early 2014 and the subsequent events in eastern Ukraine.

TABLE 2.1 Arctic Council Observer States ${ }^{106}$

\begin{tabular}{|c|c|c|c|c|c|}
\hline \multicolumn{3}{|c|}{ Alphabetical list of Observers } & \multicolumn{3}{|c|}{ Chronological list of Observers } \\
\hline State & Year appl. & Year adm. & State & Year appl. & Year adm. \\
\hline China & 2009 & 2013 & Germany & $-{ }^{a}$ & $1998^{\mathrm{b}}$ \\
\hline France & 2000 & 2000 & Netherlands & $-{ }^{a}$ & $1998^{\mathrm{b}}$ \\
\hline Germany & $-{ }^{a}$ & $1998^{\mathrm{b}}$ & Poland & $-{ }^{a}$ & $1998^{\mathrm{b}}$ \\
\hline Greece & 2014 & $-{ }^{c}$ & United Kingdom & $-{ }^{a}$ & $199^{\mathrm{b}}$ \\
\hline India & 2012 & 2013 & France & 2000 & 2000 \\
\hline Italy & 2009 & 2013 & Spain & 2006 & 2006 \\
\hline Japan & $2009^{b}$ & 2013 & China & 2009 & 2013 \\
\hline Korea (вок) & 2009 & 2013 & Italy & 2009 & 2013 \\
\hline Mongolia & 2013 & $-c$ & Japan & $2009^{b}$ & 2013 \\
\hline Netherlands & $-{ }^{a}$ & $1998^{b}$ & Korea (вок) & 2009 & 2013 \\
\hline Poland & 1996 & $1998^{b}$ & Singapore & 2011 & 2013 \\
\hline Singapore & 2011 & 2013 & India & 2012 & 2013 \\
\hline Spain & $-{ }^{a}$ & 2006 & Switzerland & 2014 & 2017 \\
\hline Switzerland & 2014 & 2017 & Mongolia & 2013 & $-c$ \\
\hline Turkey & 2013 & $-c$ & Turkey & 2013 & $-\mathrm{c}$ \\
\hline United Kingdom & $-\mathrm{a}$ & $1998^{b}$ & Greece & 2014 & $-\mathrm{c}$ \\
\hline
\end{tabular}

a continuation of accredited observer status under the AEPS.

b also present at the ceremony for the signature of the 1996 Ottawa Declaration.

c application rejected prior to the 2017 Fairbanks Ministerial Meeting.

105 'Iqaluit Declaration 2015. On the occasion of the Ninth Ministerial Meeting of the Arctic Council', adopted 24 April 2015, para 51.

106 Status as of 19 June 2017 based on information provided by the Arctic Council Secretariat. 
During the period 1996-2009, interest in category (a) Observer status with the Arctic Council was relatively minor. Four of the six Observers (Germany, the Netherlands, Poland and the United Kingdom) had already participated as accredited observers with the AEPS and only two new applications were made (France and Spain) during this period. Judging by the lack of procedural consistency on the continuation or re-accreditation of Observer status in this period, ${ }^{107}$ the Arctic States and Permanent Participants did not really consider Observer status to be an important issue. This changed profoundly in the run-up to the 2009 Tromsø Ministerial Meeting when, triggered by the events in 2007-2008 described in section 1, the Arctic States and Permanent Participants were confronted with applications by, inter alia, China, the EU, Italy and Korea.

The inability to reach consensus on these applications in 2009 was caused by a number of factors. Prominent among these was the then already ongoing debate on the strengthening or reform of the Council, including on the role therein for non-Arctic States and entities. Concerns existed that premature steps could prejudice progress. Moreover, as regards China and the EU, there were concerns that participation by these large global players might lead to the subordination of Permanent Participants to Observers within the Council. Arctic States and Permanent Participants are also likely to have had concerns on the geopolitical implications of the involvement of these two large global players as well as others that might follow in their footsteps, and a scenario where Arctic States would be outnumbered by non-Arctic States and entities. Strong sentiments and anxieties about changes to the status quo and about who 'belongs' in the Arctic and who does not, are likely to have played a role as well. This was in particular relevant for the EU application, as the EU considered imposing import restrictions on seal products at the time, thereby upsetting several Arctic States and Permanent Participants. Many of the concerns that existed in 2009 are equally, or even more, relevant today.

The 2011 Nuuk Ministerial Meeting adopted the so-called 'Nuuk Observer Rules' and decided that these would be applied to the pending applications, ${ }^{108}$ thereby deferring a substantive decision to 2013. The Task Force for Institutional Issues (TFII) established in 2011 was, inter alia, charged with amending the original (1998) Arctic Council Rules of Procedure ${ }^{109}$ to ensure the integration

107 See Molenaar, supra note 46 at $581-584$.

1082011 Nuuk Declaration, at page 2, referring to Annex 1 to Report of the May 2011 SAOs Meeting, entitled 'Framework for Strengthening the Arctic Council', containing a section entitled 'The criteria for admitting observers and role for their participation in the Arctic Council'.

1091998 Iqaluit Declaration. The Rules of Procedure are contained in Annex 1 to the Report of the September 1998 saos Meeting (on file with author). 
of the Nuuk Observer Rules, and — at a later stage — with drafting an 'Observer manual'. The amended Rules of Procedure and the 'Observer Manual for Subsidiary Bodies' were eventually adopted in $2013^{110}$ and applied to most of the then pending applications. The amendments relate in particular to Rules 37 and 38 as well as Annex 2. They comprise, inter alia, abolishment of the status of ad hoc Observer, formalisation of the review process, clarity on reaccreditation, continuation and associated decision-making, and a list of seven broad, cumulative criteria for admission.

Amended Rules 37 and 38 read as follows:

37. Once observer status has been granted, Observers shall be invited to the meetings and other activities of the Arctic Council unless SAOs decide otherwise. Observer status shall continue for such time as consensus exists among Ministers. Any Observer that engages in activities which are at odds with the Council's Declaration or these Rules of Procedure shall have its status as an Observer suspended.

38. The primary role of Observers is to observe the work of the Arctic Council. Observers contribute through their engagement in the Arctic Council primarily at the level of working groups. In meetings of the Arctic Council's subsidiary bodies to which Observers have been invited to participate, Observers may, at the discretion of the Chair, make statements after Arctic States and Permanent Participants, present written statements, submit relevant documents and provide views on the issues under discussion. Observers may also submit written statements at Ministerial meetings.

Observers may propose projects through an Arctic State or a Permanent Participant but the total financial contributions from all Observers to any given project may not exceed the financing from Arctic States, unless otherwise decided by the saOs.

The second sentence of Rule 37 clarifies that Observer status can be discontinued (suspended) at any time at the initiative of the Foreign Affairs Minister of one single Arctic State. So far, however, this has never actually happened; also not before 2013. There have so far nevertheless been at least three instances in which applications for ad hoc Observer status have been rejected, namely by

1102013 Kiruna Declaration, at page 6. An Addendum to the Observer Manual was adopted in October 2015 (Report of the October 2015 SAOs Meeting, at page 24). The consolidated version of the Observer Manual is available at https://oaarchive.arctic-council.org/ handle/11374/939, accessed 15 March 2017.

For use by the Author only | (C) 2017 Koninklijke Brill NV 
Greenpeace International (2009 and 2011) ${ }^{111}$ and by the International Fund for Animal Welfare (IFAW) sometime earlier. ${ }^{112}$ Greenpeace International applied once again prior to the 2013 Kiruna Ministerial Meeting but no decision on its application and those of several other NGOs and intergovernmental organisations has been made so far. ${ }^{113}$ At the time of writing, the Arctic Council was also reviewing all existing Observers in preparation for a formal decision on their re-accreditation at the 2017 Fairbanks Ministerial Meeting.

The balance between the rights and obligations of Observers - in particular non-Arctic States-has been a sensitive issue for a number of years. This may in part be caused by insufficient awareness among non-Arctic State Observers that current international law does not provide them with a clearly applicable and unqualified entitlement to participate in the Council; let alone a right to become a Member (see previous subsection). Some non-Arctic State Observers are nevertheless dissatisfied with their limited rights pursuant to Rules 37 and 38 and the rather broad and cumulative admission criteria laid down in paragraph 6 of Annex 2 to the Rules of Procedure.

None of the three treaties that have so far been negotiated under the auspices of the Arctic Council provide for accession by non-Arctic States and entities, regardless of them having Observer status. As regards the Arctic SAR Agreement and the Arctic mospa this is also understandable, as an entitlement under international law for them to accede cannot be readily identified. The Arctic Scientific Cooperation Agreement is a somewhat different case due to all States' entitlements on marine scientific research pursuant to UNCLOs. ${ }^{114}$ However, as the geographical scope of the Arctic Scientific Cooperation Agreement includes both land territory, coastal State maritime

\footnotetext{
111 Molenaar, supra note 46 at 582 .

112 Piotr Graczyk, 'Observers in the Arctic Council—Evolution and Prospects' (2011) 3 Yearbook of Polar Law 575 at 605, $\mathrm{n} 137$.

113 Graczyk and Koivurova, supra note 89 at 320.

114 See the Preamble and Article 6(2) of the Arctic Scientific Cooperation Agreement, and the frequent references to consistency with international law in Articles 6(1), 10 and 16. The Preamble also recognises 'the significant scientific expertise and invaluable contributions to scientific activities being made by non-Parties and specifically by the Arctic Council Permanent Participants and Arctic Council Observers'. Article 17 of the Arctic Scientific Cooperation Agreement is also very different from the virtually identical provisions included in Article 18 of the Arctic SAR Agreement and Article 17 of the Arctic MOSPA. Earlier drafts of the former were amended in response to interventions from category (a) Observers. The final version contains the phrase 'obligations of the Parties under agreements with non-Parties' and thereby implicitly the rights of non-Parties.
} 
zones and areas beyond national jurisdiction, ${ }^{115}$ it is still permissible to limit participation to Arctic States.

This distinction between the Arctic SAR Agreement and the Arctic Mospa on the one hand, and the Arctic Scientific Cooperation Agreement on the other, may also explain —in part-why the formers' negotiation-processes did not involve non-Arctic State Observers-even though some explicitly requested this ${ }^{116}$ — while the latter's negotiation-process was open to all categories of Observers, and several non-Arctic States also exercised this entitlement. But broader support for transparency and inclusiveness is likely to have been another reason for the broader participation in the third negotiation-process.

For the sake of completeness, it should be mentioned that none of the three new Arctic bodies established in 2014 and 2015 (see subsection 5.4) entitle nonArctic States to become (full) Members, with only the AORF providing observer status to petroleum safety regulatory agencies from non-Arctic States (regardless of their having Observer status with the Arctic Council)..17

In addition to broadening participation in the negotiation of the Arctic Scientific Cooperation Agreement, the Arctic Council has actively explored other opportunities for participation by Observers in Arctic Council activities ${ }^{118}$ and various formats to enable dialogue with Observers. ${ }^{119}$

\subsection{The Roles of the Arctic Council}

An appropriate point of departure for an analysis of the roles of the Arctic Council is the Council's mandate as laid down in the Ottawa Declaration. Whereas paragraph (a) of Article 1-cited above in full-lists 'cooperation, coordination and interaction', its paragraphs (b) and (c) mention the Council's role in overseeing and coordinating its Working Groups, and paragraph (d) reads 'disseminate information, encourage education and promote interest in Arctic-related issues'.

The Arctic Council's role in monitoring and assessment is probably what the Council is known best for. For the purpose of this Volume, reference can be

\footnotetext{
115 Arctic Scientific Cooperation Agreement, supra note 54, Annex 1.

116 See Molenaar, supra note 46 at $575^{-577 .}$

117 AORF Terms of Reference, Art III(1)(b).

118 E.g., participation by Observers in the June 2016 tabletop exercise on the Arctic MOSPA (EPPR Working Group Report to the October 2016 SAOs Meeting, at 1). See also the document 'Opportunities for Observer Engagement in AC Working Group Activities' (Doc ACOSUS202).

119 E.g., the 'Special Session on Observer Engagement' prior to the October 2016 SAOs Meeting.
} 
made to the Arctic Marine Shipping Assessment (AMSA). ${ }^{120}$ However, the AMSA was in fact more than an assessment as it contained negotiated policy recommendations. ${ }^{121}$ The Council's role in providing non-legally binding policy and regulatory guidance has gradually become stronger and more prominent, culminating in such outputs as policy statements, 'regulatory' guidelines, ${ }^{122}$ recommendations, and best practices. ${ }^{123}$ The non-legally binding status of these outputs is a consequence of the fact that the Council is a high-level intergovernmental forum. In case legally binding output was desirable, however, the Council resorted to its so-called 'decision-shaping' role. A good example in this regard is IMO's decision to commence negotiations on a legally binding Polar Code in response to a proposal by three Arctic Council Members, ${ }^{124}$ based on a recommendation agreed within the AMSA. ${ }^{125}$

However, the Council did not confine itself to a decision-shaping role with two other AMSA recommendations, namely in relation to search and rescue, and preparedness and response to oil pollution incidents. ${ }^{126}$ In both cases, it decided to take action to ensure regional implementation of global instruments - namely the ICAO Convention ${ }^{127}$ and the IMO's SAR Convention, OPRC 90 and Intervention Convention-by commencing negotiations for pan-Arctic instruments under its auspices.

120 The 2009 AMSA Report is available at http://www.pame.is/, accessed 15 March 2017.

121 Graczyk and Koivurova, supra note 89 at 312, refer to the AMSA as the principal example of 'second-generation' assessments.

122 E.g., the Arctic Offshore Oil and Gas Guidelines, last updated in 2009, accessed 15 March 2017 at http://www.pame.is/.

123 See, e.g., the section 'A strong Arctic Council' in the 'Vision for the Arctic' adopted at the 2013 Kiruna Ministerial Meeting, which reads, in part: 'we will continue our work to strengthen the Arctic Council to meet new challenges and opportunities for cooperation, and pursue opportunities to expand the Arctic Council's roles from policy-shaping into policy-making'.

124 IMO Doc MSC 86/23/9, 24 February 2009, submitted by Denmark, Norway and the United States.

125 See Recommendation I(B), 2009 AMSA Report, supra note 120 at 6. For some other examples, see Terry Fenge, 'Canada and the Arctic Council: Our Turn to Conduct the Arctic Orchestra' (2012) April Policy Options 54-58 at 55.

126 Ibid., Recommendations I(E) and III(C).

127 Convention on International Civil Aviation, adopted 7 December 1944, 15 UNTS 295 (entered into force 4 April 1947). 


\subsection{The Arctic Council System (Acs)}

This author introduced the concept of the ACs some years ago to clarify that legally binding instruments such as the Arctic SAR Agreement and the Arctic MOSPA - and their institutional components — can be part of the Council's output even though they are not formally adopted by it due to the fact that the Council is a high-level intergovernmental forum. ${ }^{128}$ Whereas the concept of the Antarctic Treaty System (ATS) has been formally recognised by the Antarctic Treaty Consultative Parties, the concept of the ACs has not been formally recognised by the Council's Members and Permanent Participants. In fact, the acronym Acs is currently widely used to denote the Arctic Council Secretariat. ${ }^{129}$

The Acs concept consists of two basic components. The first component is made up of the Council's constitutive instrument, other Ministerial Declarations, other instruments adopted by the Arctic Council, and the Council's institutional structure. The second component consists of legally binding instruments negotiated under the Council's auspices and their institutional components. The Arctic SAR Agreement and the Arctic MOSPA as well as their MOPs ${ }^{130}$ belong to this category, and so will the future Arctic Scientific Cooperation Agreement and its MOPs. ${ }^{131}$

The linkage between the Council and this second component is not confined to the instruments' mere negotiation under the Council's auspices, but also comprises a considerable and increasing extent of substantive and institutional integration. This relates in particular to the role of the EPPR Working Group under the Arctic MOSPA as well as the Arctic SAR Agreement. As regards the former, not only was EPPR closely involved during its negotiation-in particular by developing its Appendix IV 'Operational Guidelines' - but in 2013 it was also tasked to ensure that Appendix IV remains up to date. ${ }^{132}$ Among the implementation activities undertaken by EPPR are those developed by its Exercise Design Team (EDT), for instance:

\footnotetext{
128 Molenaar, supra note 46.

129 The acronym ATs is occasionally also used to denote the Antarctic Treaty Secretariat.

130 Articles 10 and 14, respectively.

131 Article 12 of the Agreement, supra note 54, entitled 'Review of this Agreement', envisages meetings of the Parties. Takei, supra note 90 at $35^{6-359}$, discusses Russian proposals for a legally binding instrument on search and rescue between the Arctic Council Members during 2003-2005.

132 Report of the October 2013 SAOs Meeting, at 11. Article 20(1) of the Arctic MOsPa stipulates that its Appendices are not legally binding.
} 
1. A workshop aimed, among other things, identifying the highest risk Arctic spill scenarios (September 2015); ${ }^{133}$

2. A 'Connectivity Test' of competent authorities listed in the Operational Guidelines (January 2016);134 and

3. The second functional table-top exercise (13 June 2016), which led to the adoption of an After Action Report, whose recommendations will be addressed by the recently established Marine Environmental Response Experts Group. ${ }^{135}$

As regards EPPR's role vis-à-vis the Arctic SAR Agreement, EPPR's mandate was broadened in 2015 to include search and rescue, and to ensure follow-up in relation to the Arctic SAR Agreement. ${ }^{136}$ The October 2015 Arctic Zephyr Tabletop Exercise identified shortcomings on cooperation and coordination in the context of the Arctic SAR Agreement, and made recommendations to address them. ${ }^{137}$ In December 2015, EPP R established a SAR Expert Group-led by Norway—which had its 2nd Meeting in June $2016 .^{138}$

This significant substantive and institutional integration of EPPR with the Arctic SAR Agreement and the Arctic MOSPA raises the question of what role remains for the MOPs envisaged under Article 10 of the Arctic SAR Agreement and Article 14(1) of the Arctic Mospa. At the time of writing, no such MOPs have been convened. As regards the Arctic MOSPA, however, this is expected to change soon, as its Article 14(1) reads, in part:

The Parties shall meet no later than one year after the entry into force of this Agreement, as convened by the depositary, and from then on as decided by the Parties. [...] Parties may elect to convene such meetings in conjunction with meetings of the Arctic Council. ${ }^{139}$

133 'Background Paper: 2nd Functional Exercise of the Mospa Agreement' to the March 2016 SAOs Meeting (Doc ACSAOUS202).

134 Ibid.

135 EPPR Working Group Report to the October 2016 SAOs Meeting, at 1.

136 Report of the March 2015 SAOs Meeting, at 17-18 (Doc ACSAO-CA04; and Report of the April 2015 SAOs Meeting, at 26 and 28.

137 Presentation by Amy Merten, Chair of the EPPR Working Group, at the March 2016 sAOs Meeting (slides 4-8).

138 EPPR Working Group Report to the October 2016 sAOs Meeting, at 1.

139 The wording of Article 10 of the Arctic SAR Agreement is markedly different, however, as it reads, in part: 'The Parties shall meet on a regular basis in order to consider and resolve issues regarding practical cooperation'. 
In light of the Agreement's entry into force on 25 March 2016, the depositary (Norway) was consulting with the SAOs of the other Contracting Parties on when and how to organise the 1st MOP..$^{140}$

The situation with the Arctic Scientific Cooperation Agreement is somewhat different, as none of the existing Arctic Council bodies is an obvious candidate to perform an implementation or other role under this Agreement. Its Article 12(1) contains wording that is virtually identical to that in Article 14(1) of the Arctic MOSPA cited above, but also adds: 'including inviting Arctic Council Permanent Participants and Arctic Council Observers to observe and provide information'. It is submitted that this advances integration with the Arctic Council even further.

Three other Arctic bodies have been established in recent years: the Arctic Economic Council (AEC), the Arctic Offshore Regulators Forum (AORF) and the Arctic Coast Guard Forum (ACGF). While none of them has been formally established by the Council or pursuant to a legally binding instrument negotiated under the Council's auspices, all have linkages with the Council. ${ }^{141}$

The AEC was established in September 2014, six months after the Arctic Council's Task Force to Facilitate the Creation of a Circumpolar Business Forum (ТFCBF) completed its work by presenting its report to the March 2014 soAs Meeting, and the SAOs approved the document 'Facilitating the Creation of the Arctic Economic Council'.142 At the 2016 Annual AEc Meeting, the delegates adopted the AEC's Rules of Procedure, its Strategic Plan for the years 2016-2018, the various Membership Dues \& Classes, and its Membership Application Process. ${ }^{143}$ These indicate, inter alia, that: the AEC is an independent business NGO governed by Norwegian law; whose business representatives are nominated by Arctic States and Permanent Participants (so-called 'Legacy Members'); whose Executive Committee's Chair will in principle have

140 Information provided by a Norwegian official to the author on 23 November 2016.

141 At the March 2015 SAOs Meeting, the United States proposed the establishment of a body like the AORF (Report of the March 2015 SAOs Meeting, at 9). The Report also notes: 'The U.S. proposed to help clarify the relationship between the AC and this proposed regulators' forum as well as other forums operating outside the Arctic Council (for example, the Arctic Economic Council, Arctic Coast Guard Forum and Arctic Regional Hydrographic Commission)'. However, such a clarification has so far not materialised, whether in the AORF Terms of Reference or otherwise. An earlier proposal for a body like the AORF was made at least as early as October 2013 during an Arctic Offshore Regulator's Meeting, using the International Regulators' Forum as a model (Arctic Offshore Regulator's Meeting, Stavanger, Norway, 31 October 2013. Minutes of Meeting are on file with author).

142 Report of the March 2014 SAOs Meeting, at 6 and Annex.

143 Accessed 15 March 2017 at http://arcticeconomiccouncil.com/. 
the nationality of the Arctic State chairing the Arctic Council; and which offers 'non-voting membership' to so-called 'Southern Partners.' ${ }^{44}$ One of the four AEC working groups is entitled 'Maritime transportation infrastructure'.

The AORF was established at its inaugural meeting on 30 April and 1 May 2015 and builds on the efforts of the Arctic Council's Task Force on Arctic Marine Oil Pollution Prevention (TFOPP), whose 'Framework Plan for Cooperation on Prevention of Oil Pollution from Petroleum and Maritime Activities in the Marine Areas of the Arctic' (Framework Plan) was accepted by the SAOs in March 2015. ${ }^{145}$ The Framework Plan contains several general provisions relating to implementation by national authorities as well as cooperation among national regulators, ${ }^{146}$ but no institutional component.

The AORF's Terms of Reference specify that it is an intergovernmental forum with membership limited to Arctic States, represented by their offshore petroleum regulatory agencies. ${ }^{147}$ Instead of referring to the Framework Plan, Article II(2)(a) of the AORF Terms of Reference specifies that one of the objectives of the AORF is furthering the recommendations of the TFOPP 'to enhance the capacity of Arctic offshore petroleum safety regulators to prevent marine oil pollution through regular exchanges of knowledge and experience'. The composition of the AORF Management Committee is coordinated with the chairmanship of the Arctic Council. ${ }^{148}$ Rather than mentioning particular Arctic Council bodies, Article II(1)(c) of the AORF Terms of Reference stipulates that the AORF 'may collaborate with the Arctic Council and other international fora, as appropriate.' The PAME and EPPR Working Groups would nevertheless be of principal importance.

In contrast with the AEC and the AORF, the establishment of the ACGF in October 2015 did not follow preparatory work by an Arctic Council body, whether a Task Force or some other body. The ACGF is an independent, intergovernmental forum whose memberships consists of 'Agencies Representing Coast Guard Functions' of the Arctic States aimed, among others, at supporting 'agreements between Arctic States, such as those made under the auspices

\footnotetext{
144 Sections 2.9, 4.1(v) and 7.2(i) of the AEC Rules of Procedure and the document 'Membership Dues \& Classes'.

145 Report of the March 2015 SAOs Meeting, at 9. The text of the Framework Plan is included in the April 2015 SAOs Report to Ministers, at 110-117.

146 Framework Plan, supra note 145, Arts 1.6.1 and 2.3(a).

147 AORF Terms of Reference', Arts II(1)(a) and III(1)(a), accessed 15 March 2017 at https:// www.bsee.gov/what-we-do/international-engagement/forums.

148 Ibid., Arts IV(2) and v(1).
} 
of the Arctic Council, related to coast guard functions. ${ }^{149}$ Rather than merely complementing the Council or the ACS, such support can be regarded as implementation of the Arctic SAR Agreement and the Arctic MOSPA. In light of the exclusion of 'matters related to military security' of the Council's mandate, it is worth noting that neither the ACGF Joint Statement nor the ACGF Terms of Reference ${ }^{150}$ use the word 'military' in conjunction with 'security'. As six of the eight participating Agencies have a military or semi-military character, ${ }^{151}$ however, it may ultimately also serve as a cooperative mechanism to fill this gap in the Council's mandate. A significant extent of institutional integration between the ACGF and the Arctic Council exists as well. The ACGF will be led by a Chair that rotates in tandem with the chairmanship of the Arctic Council, ${ }^{152}$ and there is ample evidence of increasingly close cooperation and coordination with the EPPR Working Group. ${ }^{153}$

The brief analysis of these three recently established Arctic bodies reveals a varying extent of integration - substantively as well as institutionally - with the Arctic Council and the ACS. The ACGF appears to be the most integrated and the AEC the least. ${ }^{154}$ However, none of the bodies are part of the Council because they were not formally established by the Council. Also, none were established pursuant to a legally binding instrument negotiated under the Council's auspices. For the time being, the latter criterion is an objective and useful criterion for determining whether or not a body belongs to the ACs.

Leaving definitional issues aside, however, it would be quite understandable if the establishment of three new Arctic bodies within such a short time-span would be regarded as institutional proliferation. Increased efforts on institutional coordination and cooperation seem at any rate justified. The Arctic Council's 2016 Guidelines for Relationships with Outside Bodies ${ }^{155}$ may be of some help in this regard.

149 ACGF Joint Statement, supra note 88, and ACGF Terms of Reference, supra note 88 at (i) and (xxii).

$150 \quad$ Supra note 88.

151 Østhagen, supra note 88.

152 Ibid. at (v).

153 See, for instance, EPPR Progress Report to the March 2016 sAOs Meeting, at 2.

154 At the October 2016 SAos Meeting, only a few Arctic States were interested in formalising the relationship between the Arctic Council and the AEC. Report of the October 2016 SAOs Meeting, at 24.

155 As adopted by the March 2016 sAos Meeting. 

of International Law

The Arctic Council is at present generally accepted by the international community as the principal intergovernmental body for Arctic cooperation. The Council's primacy in this regard is, inter alia, underscored by the significant interest of non-Arctic States in obtaining Observer status with the Council; in particular since 2008 (see subsection 5.2 above). Milestones of the Council's pathway to primacy are its contribution to the $2004 \mathrm{ACIA}$ - which broadened recognition within the international community that climate change is largely driven by anthropogenic pollution - and its 2009 AMSA Report, which delivers on the need to address inadequacies in the international governance and regulatory regime of the marine Arctic in light of climate change.

The main challenge to the Council's crystallising primacy was-arguablyposed by the high-level cooperation between the Arctic Five following the Russian Federation's planting of its flag on the geographical North Pole's deep seabed in 2007. The convening of the May 2008 Ilulissat ministerial (foreign affairs) meeting and the adoption of its declaration were criticised by the Arctic Council's other three Members and its permanent participants for undermining the Arctic Council. ${ }^{156}$ The Arctic Five nevertheless convened once again at ministerial (foreign affairs) level in March 2010, in Chelsea, Canada. At that meeting, however, the us Secretary of State Clinton expressed doubts and concerns over the appropriateness of ministerial (foreign affairs) meetings of the Arctic Five, ${ }^{157}$ and no such further meetings have since taken place. The highlevel participation at the Arctic Council's 2011 Nuuk Ministerial Meeting-in particular by the United States, which was represented not only by Secretary of State Clinton but also by the Secretary of the Interior Salazar-was another clear sign of the Arctic Five's full support for the Arctic Council.

The 2008 Ilulissat Declaration not only emphasised the applicability of the international law of the sea to the Arctic Ocean, but also observed that the Arctic Five saw 'no need to develop a new comprehensive international legal regime to govern the Arctic Ocean'. This responded to proposals such as those of the World Wide Fund for Nature (WWF) for a 'regional agreement on the management and conservation of the Arctic marine environment' early in

156 See e.g., Report of the April 2010 SAOs Meeting, at para 20; and 'A Parliamentary Resolution on Iceland's Arctic Policy', approved by the Althingi at its 139th legislative session, on 28 March 2011 (on file with author), at Principle No 1 (including Commentary, at 4-6).

157 Torbjørn Pedersen, 'Debates over the Role of the Arctic Council' (2012) 43 Ocean Development \& International Law 146 at 152. 
2008. ${ }^{158}$ Another-but very different-proposal was that by the European Parliament in its Resolution of 9 October 2008 on 'Arctic governance' for a 'treaty for the protection of the Arctic, having as its inspiration the Antarctic Treaty, as supplemented by the Madrid Protocol signed in 1991. ${ }^{159}$ The United States dismissed this idea in its Arctic Region Policy as 'not appropriate or necessary'. ${ }^{160} \mathrm{~A}$ further, more elaborate proposal by wWF for a regional framework instrument for the marine Arctic, launched in early 2010, ${ }^{161}$ could not attract sufficient support either.

Rather than a comprehensive reform or overhaul, the Council eventually decided on a two-tiered approach of adaptation, namely by strengthening the Arctic Council as such ${ }^{162}$ - for instance by the establishment of the Arctic Council Secretariat and the use of assessed contributions - and by the ACs concept. It is submitted that the establishment of the Arctic Council Secretariat did not transform the Council's pre-existing status as a high-level intergovernmental forum into that of an intergovernmental organisation. ${ }^{163}$ However, determining this status is admittedly not a straightforward matter due to the absence of a generally accepted definition of 'intergovernmental organization. ${ }^{\prime} 64$ The establishment of a permanent secretariat is nevertheless not a decisive factor. This is, inter alia, illustrated by the establishment of the

$15^{8}$ Rob Huebert and Brooks B Yeager, A New Sea. The Need for a Regional Agreement on the Management and Conservation of the Arctic Marine Environment (WWF, 2008) accessed 15 March 2017 at wwf.panda.org/arctic.

159 Supra note 4.

16o National Security Presidential Directive/NSPD-66 \& Homeland Security Presidential Directive/HSPD-25, 9 January 2009, at Sec III(C)(3), accessed 15 March 2017 at https://fas .org/irp/offdocs/nspd/nspd-66.htm.

161 Timo Koivurova and Erik J Molenaar, International Governance and Regulation of the Marine Arctic. (wwF, 2010) accessed 15 March 2017 at www.panda.org/arctic. The 3 rd Report in this publication is entitled A Proposal for a Legally Binding Instrument.

162 'Strengthening the Arctic Council' is a separate section in the 2013 (Kiruna) and 2015 (Iqaluit) Ministerial Declarations and has been a standing agenda item for SAOs Meetings in recent years.

163 Takei, supra note 90 at $353-355$. Contra Byers, supra note 23 at 9.

164 As the definition agreed by the International Law Commission in 2003 ('Report of the International Law Commission. Fifty-fifth Session' (5 May-6 June and 7 July-8 August 2003) General Assembly Official Records 58th Session Supp 10), at 38) was developed in the context of the issue of international responsibility of international organisations, some commentators regard it as inadequate. See Kirsten Schmalenbach, 'International Organizations or Institutions, General Aspects', Max Planck Encyclopedia of Public International Law (December 2006) at para 3; and Robin R Churchill and Geir Ulfstein, 'Autonomous Institutional Arrangements in Multilateral Environmental Agreements: 
Antarctic Treaty Secretariat in 2004, which was not regarded as having transformed the Antarctic Treaty's decision-making body-the Antarctic Treaty Consultative Meeting - into an intergovernmental organisation. The status of an intergovernmental body is above all determined by the positions of relevant States in this regard. It is in this light sufficient to observe that there are no indications that any of the Arctic Council Members regard the Council at present as an intergovernmental organisation.

The question nevertheless remains whether the current institutional set-up of the Council will be sufficient to address future challenges and ambitions. While support for re-establishing the Council pursuant to a treaty has in the recent past also been expressed by Arctic Council participants-namely by Finland ${ }^{165}$ and the Conference \& Standing Committee of Parliamentarians of the Arctic Region ${ }^{166}$ — the required consensus among the Arctic Council Members to commence such negotiations is not even remotely in sight. A key concern of the Permanent Participants is the risk of losing the very influential participatory status they currently have in the Arctic Council. As international law is inherently dynamic, however, nothing fundamental prevents the Arctic States from progressively developing international law by giving Arctic indigenous peoples a similar participatory status under a treaty. ${ }^{167}$

At the time of writing, discussions on the development of an Arctic Council Strategic Plan and within the Task Force on Arctic Marine Cooperation (TFAMC) indicated that there is a quite minimal appetite for institutional change. As regards the Arctic Council Strategic Plan, delegations at the October 2016 SAOs

A Little-Noticed Phenomenon in International Law' (2000) 94 American Journal of International Law 623-659, at 632-633.

165 Finland's Strategy for the Arctic Region 2013 (adopted by Government Resolution on 23 August 2013; Prime Minister's Office Publications No 16/2013) at 44. See Page Wilson, 'An Arctic Council Treaty? Finland's Bold Move', Arctic Yearbook 2014, Commentaries, Sec 18, accessed 15 March 2017 at http://www.arcticyearbook.com.

166 See Paragraph 1 of the Conference Statement adopted at the Arctic Parliamentarians' 1oth Conference in 2012, which is based on the Report entitled 'Arctic Governance in an Evolving Arctic Region' drawn up by the Standing Committee of Parliamentarians of the Arctic Region. However, the 11th Conference Statement (2014) does not re-affirm such support, with Paragraph 16 merely asking key decision-making authorities to 'Explore new areas for legally binding agreements between the Arctic countries'. The 12th Conference Statement (2016) no longer makes any reference to the issue. All documents accessed 15 March 2017 at http://www.arcticparl.org/.

167 See also the subsection 'International Indigenous Human Rights Standards' in Chapter 3 of this Volume. 
Meeting did not seem interested in considering the Council's structure or its relationship to external bodies. ${ }^{168}$

The TFAMC has a mandate to 'assess future needs for a regional seas program or other mechanism, as appropriate, for increased cooperation in Arctic marine areas'. ${ }^{169}$ In its report to the 2017 Ministerial Meeting, the TFAMC must identify 'future needs for strengthened cooperation for Arctic marine areas, as well as whether the Council should begin negotiations on a cooperation mechanism for Arctic marine areas-ideally naming the specific mechanism —and/or any other recommendations it may deem appropriate. ${ }^{\prime 170}$ At the time of writing, the TFAMC had met four times and appeared to have reached preliminary agreement on the envisaged cooperative mechanism's functions (e.g., furthering implementation of an ecosystem approach to oceans management as well as implementation of the Arctic Council's marine 'output' more in general), but not on its form. While wide support existed for establishing a new body in which 'senior marine managers' would participate, there seemed to be only minimal support to establish this body under a legally binding instrument and empower it to adopt legally binding decisions. ${ }^{171}$

In particular, the Russian Federation seemed to have serious concerns relating to any initiative that could potentially lead to restrictions on economic development in the 'Russian Arctic'. It is important not to lose sight of geographical considerations in this regard. Arguably, about half of the Arctic is Russian and the same could be said of that part of the marine Arctic that consists of coastal State maritime zones. If the TFAMC would opt for something modelled on the OSPAR Commission ${ }^{172}$ - and assuming that the OSPAR Commission would not relinquish its competence in the Atlantic sector of the Arctic Ocean ${ }^{173}$ - more than half of the remaining marine area would consist

168 Report of the October 2016 SAOs Meeting, at 19; 'Towards an Arctic Council Strategic Plan-Discussion Paper' (Doc ACSAOUS203).

1692015 Iqaluit Declaration, supra note 105 at 5 . The Terms of Reference of the TFAMC are included in the Report of the April 2015 Iqaluit sAos Meeting, at 77-78.

170 TFAMC Terms of Reference, supra note 169 at 77.

171 Report of the October 2016 saOs Meeting, at 21-22.

172 Established by the Convention for the Protection of the Marine Environment of the NorthEast Atlantic, adopted 22 September 1992, 2345 UNTS 67 (entered into force 25 March 1998) as amended. Annex V 'On the Protection and Conservation of the Ecosystems and Biological Diversity of the Maritime Area,' adopted 23 September 1998 (entered into force 30 August 2000) as amended. Consolidated text accessed 15 March 2017 at http://www .ospar.org/.

173 Similarly, the North-East Atlantic Fisheries Commission (NEAFC) can be assumed not to be willing to relinquish its competence in the Atlantic sector in deference of a 
of the Russia's maritime zones. In addition, four Members have no coastal State maritime zones in the remaining area at all, namely Finland, Iceland, Norway and Sweden. It is therefore not difficult to imagine that ambitious and 'costly' proposals by these four could be perceived by the Russian Federation as insincere and unbalanced, as they impose no burden on them and a very heavy burden on the Russian Federation. Finally, it should not be forgotten that-despite encouragement ${ }^{174}$ — the Russian Federation has not become a Member of the ospar Commission, even though the ospar Maritime Area overlaps with Russia's maritime zones.

The pace and direction of progress within the TFAMC is also influenced by the pace and direction of progress within the PrepCom of the BвNJ Process. ${ }^{175}$ Some, if not all, Arctic States are likely to proceed cautiously in both processes in order to ensure coherence between their positions and thereby avoid compromising their positions and interests.

Recent developments in the OSPAR Commission relating to a proposal for an OSPAR 'Arctic Ice High Seas M PA' in OSPAR Region I (Arctic Waters) should be highlighted as well. At the meeting of the OSPAR Commission's Biodiversity Committee in early 2016, the Kingdom of Denmark objected to further consideration of this proposal within the OSPAR Commission, inter alia, referring to the on-going work of the Arctic Council's TFAMC as well as the overlap between the proposed MPA and areas included in the Kingdom of Denmark's submission to the CLCS. ${ }^{176}$ Subsequently, Iceland and Norway sided with the Kingdom of Denmark, jointly taking the view that area-based management measures in the 'Central Arctic Ocean' are better left to the Arctic Council, inter alia, due to participation of all relevant coastal States in that body. ${ }^{177}$ It

future RFMo/A established as a follow-up of the on-going 'Five-plus-Five' meeting. See Molenaar, supra note 37 and accompanying text.

174 Olav S Stokke, 'A Legal Regime for the Arctic? Interplay with the Law of the Sea Convention', (2007) 31 Marine Policy 402-408, at 406.

175 Supra note 9.

176 Summary Record of the 16th BDC Meeting (2016; Doc BDC 16/9/1-E) at para 5.13. The proposal is contained in Doc BDC 16/05/04 Rev.1.

177 Summary Record of the 16th OSPAR Commission Meeting (2016; Doc OSPAR 16/20/1-E) at para $6.27(\mathrm{c})$, which also mentions that the three States had made a similar statement at HOD 16. It is not clear if, in response to the lack of consensus among OSPAR Members, qualified majority voting was considered or proposed. Article 13(1) of the OSPAR Convention stipulates that decisions and recommendations are adopted by 'unanimous vote' and, in case unanimity is not attainable, decisions and recommendations can be adopted by a 'three-quarters majority vote'. Decision-making in the OsPAR Commission occurs in practice by consensus, however, and qualified majority voting is resorted to 
is submitted that these three Arctic States thereby implicitly assert the Arctic Council's primacy over the OSPAR Commission as regards area-based management measures in the overlap-area between OSPAR Region I and the area they refer to as the 'Central Arctic Ocean'. However, the Arctic Council's output on area-based management has so far ${ }^{178}$ been fundamentally different from that of the OSPAR Commission, notably due to the former's lack of multilateral designation and adoption of associated restrictions on human activities. One of the concrete implications of the abovementioned primacy-assertion is therefore that adoption of area-based management measures in the overlap-area between OSPAR Region I and the 'Central Arctic Ocean' that are both multilateral and multi-sectoral cannot be expected in the near future.

Conclusions

As was pointed out early on in this Chapter, the global component of the law of the sea also applies to the marine Arctic. The same is in fact true for global instruments and bodies that belong to other domains of international law. While a legal vacuum therefore does not exist at the global level, in view of the current and projected impacts of climate change, the marine Arctic evidently needs tailor-made implementation of these global instruments, including by regional bodies such as the Arctic Council.

Except for the tiny Hans Island-which is claimed by Canada as well as Denmark/Greenland - there are no disputes on title to territory in the Arctic. As nothing remotely similar to the fundamental disagreement on title to territory in Antarctic exists in the Arctic, the Antarctic Treaty is clearly not a suitable model for the Arctic.

Apart from archipelagic waters, all the generally accepted maritime zones also occur in the marine Arctic. This, and the absence of significant disputes on title to territory, means that, from a law of the sea perspective, the marine Arctic is not really different from other marine regions and Oceans, with the notable exception of Article 234 of UNCLOS. It is submitted that this general conclusion is not affected by Arctic-specific practices (e.g., the Fisheries Protection

only rarely. See 'List of Decisions, Recommendations and Other Agreements Applicable within the Framework of the OSPAR Convention-Update 2016', accessed 15 March 2017 at http://www.ospar.org/convention/agreements.

178 This consists above all of the 'Framework for a Pan-Arctic Network of Marine Protected Areas', adopted by the PAME Working Group in April 2015, accessed 15 March 2017 at http://www.pame.is/index.php/document-library/pame-reports. 
Zone established by Norway around Svalbard, and the Russian Federation's ambiguous - but also unpredictable - reliance on the sector theory), Arcticspecific disputes (e.g., on straight baselines, historic title or waters, the regime of navigation in (parts of) the Northwest Passage and the Northern Sea Route, and the geographical scope of the Spitsbergen Treaty) or the unresolved maritime boundaries and limits in the marine Arctic.

The global component of the international law relating to international merchant shipping also applies to the marine Arctic. UNCLOS is the cornerstone of this global component, and recognises or establishes the navigational rights and freedoms of flag States, the jurisdictional balance on navigation between flag, coastal and port States, and IMo's key role in ensuring globally uniform minimum regulation. However, whereas Imo's primacy in the international regulation of international merchant shipping is generally accepted, regional action relating to merchant shipping can still be useful or desirable, and is not necessarily inconsistent with UNCLOS. Cases in point are the Arctic SAR Agreement and the Arctic mosPa negotiated under the Arctic Council's auspices to ensure regional implementation of IMO instruments. Other domains for which regional action would not lead to incompatibility or conflict with IMO output include monitoring, surveillance, inspection, and enforcement as well as the international law of the sea (e.g., resolving disputes or furthering implementation).

The pace in which the Arctic Council has evolved since its establishment in 1996 is significant. Milestones in this evolution were the establishment of the Arctic Council Secretariat and the de facto creation of what this author has called the concept of the Arctic Council System (ACS). The ACs concept consists of two basic components. The first is made up of the Council's constitutive instrument, other Ministerial Declarations, other instruments adopted by the Arctic Council and the Council's institutional structure. The second component consists of legally binding instruments negotiated under the Council's auspices and their institutional components. The linkage between the two components comprises a considerable and increasing extent of substantive and institutional integration. This relates in particular to the role of the EPPR Working Group.

In 2014 and 2015, the Arctic's institutional complexity increased further by the establishment of three new bodies, namely the AEC, the AORF and the ACGF. While none of these has been formally established by the Council or pursuant to a legally binding instrument negotiated under its auspices, all three have different extents of integration-substantively as well as institutionallywith the Arctic Council and the broader Acs. Rather than forming part of the Council or the broader ACs, however, they could be regarded as belonging to 
a new, more peripheral category of Arctic cooperative mechanisms. The establishment of these new bodies may well be regarded as institutional proliferation, and require at any rate increased efforts on institutional coordination and cooperation. The Arctic Council's 2016 Guidelines for Relationships with Outside Bodies may be helpful in this regard.

Even though the Arctic Council's substantive mandate is almost unlimited, but at present significantly under-utilised, more optimal use and associated institutional change is in principle constrained by existing (sub-)regional or bilateral instruments and bodies. As a general rule, ${ }^{179}$ it can be assumed that the Arctic States have no desire to replace or subsume existing (sub-)regional or bilateral instruments and bodies, or to preclude new (sub-)regional or bilateral instruments and bodies from being created. Pertinent examples are instruments and bodies relating to the conservation and management of marine mammals and fish stocks, for instance the currently on-going Five-plus-Five process on international regulation of high seas fishing in the central Arctic Ocean. In view of the widening acceptance of ecosystem-based ocean management, however, one would expect increasingly closer coordination and cooperation between the Arctic Council and these formally stand-alone instruments and bodies.

Further evolution of the Council and the broader ACs seems inevitable, but the timeframe in which this is to occur is very uncertain. One wildcard in this regard is the commencement of the United States' Trump Administration in January 2017. While the broader ACS will at any rate expand further with the envisaged adoption of the Arctic Scientific Cooperation Agreement in conjunction with the Arctic Council's Ministerial Meeting in 2017, the discussions on the Arctic Council Strategic Plan and the slow progress in the TFAmC towards the end of 2016, suggest that further evolution will occur later rather than sooner.

179 While the Kingdom of Denmark, Iceland and Norway have implicitly asserted that the Arctic Council has primacy over the OSPAR Commission as regards area-based management measures in the overlap-area between OSPAR Region I and the area they refer to as the 'Central Arctic Ocean', it is too early to assess if this amounts to an exception to this general rule. 